\title{
Transfer of environmental signals from the surface to the underground at Ascunsă Cave, Romania
}

\author{
Virgil Drăguşin ${ }^{1}$, Sorin Balan ${ }^{2}$, Dominique Blamart ${ }^{3}$, Ferenc Lázár Forray ${ }^{4}$, Constantin Marin ${ }^{1}$, Ionuţ Mirea ${ }^{1,4}$, \\ Viorica Nagavciuc $^{5}$, Iancu Orăşeanu ${ }^{6}$, Aurel Perşoiu ${ }^{5,7}$, Laura Tîrlă ${ }^{8}$, Alin Tudorache ${ }^{1}$, and Marius Vlaicu ${ }^{1}$ \\ ${ }^{1}$ Emil Racoviţă Institute of Speleology, Frumoasă 31, 010986, Romania \\ ${ }^{2}$ National Research and Development Institute for Marine Geology and Geoecology, Mamaia 304, Constanţa, \\ 900581, Romania \\ ${ }^{3}$ Laboratoire des Sciences du Climat et de l'Environnement LSCE-IPSL CEA-CNRS-UVSQ, Paris-Saclay, \\ Avenue de la Terrasse, Bât. 12, 91198 Gif-sur-Yvette CEDEX, France \\ ${ }^{4}$ Department of Geology, Babeş-Bolyai University, Kogălniceanu 1, 400084 Cluj-Napoca, Romania \\ ${ }^{5}$ Stable Isotope Laboratory, Ştefan cel Mare University, Universităţi 13, Suceava 720229, Romania \\ ${ }^{6}$ Romanian Association of Hydrogeologists, Traian Vuia 6, Bucharest 020956, Romania \\ ${ }^{7}$ Emil Racoviţă Institute of Speleology, Clinicilor 5, Cluj Napoca 400006, Romania \\ ${ }^{8}$ Faculty of Geography, University of Bucharest, N. Bălcescu 1, Romania
}

Correspondence to: Virgil Drăguşin (virgil.dragusin@iser.ro)

Received: 25 November 2016 - Discussion started: 4 January 2017

Revised: 14 September 2017 - Accepted: 20 September 2017 - Published: 26 October 2017

\begin{abstract}
We present here the results of a 4-year environmental monitoring program at Ascunsă Cave (southwestern Romania) designed to help us understand how climate information is transferred through the karst system and archived by speleothems. The air temperature inside the cave is around $7^{\circ} \mathrm{C}$, with slight differences between the upper and lower parts of the main passage. $\mathrm{CO}_{2}$ concentrations in cave air have a seasonal signal, with summer minima and winter maxima. These might indicate the existence of an organic matter reservoir deep within the epikarst that continues to decompose over the winter, and $\mathrm{CO}_{2}$ concentrations are possibly modulated by seasonal differences in cave ventilation. The maximum values of $\mathrm{CO}_{2}$ show a rise after the summer of 2014, from around 2000 to about $3500 \mathrm{ppm}$, following a rise in surface temperature. Using two newly designed types of water-air equilibrators, we were able to determine the concentration of $\mathrm{CO}_{2}$ dissolved in drip water by measuring its concentration in the equilibrator headspace and then using Henry's law to calculate its concentration in water. This method opens the possibility of continuous data logging using infrared technology, without the need for costly and less reliable chemical determinations. The local meteoric water line $\left(\delta^{2} \mathrm{H}=7.7 \delta^{18} \mathrm{O}+10.1\right)$, constructed using monthly ag-
\end{abstract}

gregated rainfall samples, is similar to the global one, revealing the Atlantic as the strongly dominant vapor source. The deuterium excess values, as high as $17 \%$, indicate that precipitation has an important evaporative component, possibly given by moisture recycling over the European continent. The variability of stable isotopes in drip water is similar at all points inside the cave, suggesting that the monitored drip sites are draining a homogenous reservoir. Drip rates, as well as stable isotopes, indicate that the transfer time of water from the surface is on the order of a few days.

\section{Introduction}

The large-scale monitoring of karst systems is mainly undertaken from the perspective of water resource management or conservation (e.g., White, 1988; Ford and Williams, 2013). However, with the use of speleothems as tools for climate reconstruction came the need for monitoring karst systems at a much finer spatial and temporal scale, where water-rock and water-atmosphere interactions have to be taken into account (Fairchild and Baker, 2012). In speleothem paleoclimatology, cave monitoring studies are used as tools for local, case- 
by-case calibration of speleothem proxies against climate parameters and were employed throughout the world: Gibraltar (Mattey et al., 2008), Belgium (Verheyden et al., 2008; Van Rampelbergh et al., 2014), France (Genty et al., 2014), the Czech Republic (Faimon et al., 2012), Spain (Smith et al., 2016; Dumitru et al., 2017), Austria (Spötl et al., 2005), Germany (Riechelmann et al., 2013), USA (Onac et al., 2008; Feng et al., 2014; Meyer at al., 2014), Australia (Jex et al., 2012) or China (Hu et al., 2008; Duan et al., 2016). Such studies focus mainly on parameters such as cave air temperature and relative humidity, $\mathrm{CO}_{2}$ concentration in drip water and cave atmosphere, or stable isotope ratios in drip water and modern calcite. Lately, a series of review papers have detailed the systematics of stable isotopes in speleothems (McDermott, 2004; Fairchild et al., 2006; Lachniet, 2009), while the book of Fairchild and Baker (2012) offers an updated and detailed framework for speleothem paleoclimatology.

Water is the main carrier of information between surface climate and speleothems; thus, the most used paleoclimate proxy is $\delta^{18} \mathrm{O}$. The interpretation of speleothem $\delta^{18} \mathrm{O}$ values is not usually straightforward because they are influenced by thermal and hydrological processes both at the surface and underground, sometimes in opposing ways. For example, at the surface, the altitude effect could be counteracted by a rain shadow effect, as evidenced in the Andes by Chamberlain and Poage (2000). Seasonal changes in the vapor source of rainfall or in conditions at the vapor source can modify the annual $\delta^{18} \mathrm{O}$ values of rain water and represent an important issue in speleothem paleoclimate reconstructions. Information on the vapor source is usually inferred based on the meteoric water line and the deuterium excess value in precipitation (Craig, 1961; Gat, 1996; Pfahl and Sodemann, 2014). When entering the soil-karst system, water can be subjected to evaporation in the soil, the epikarst or even in the cave, thus imprinting higher values to calcite than the original rainfall (Bar Matthews et al., 1996; Markowska et al., 2016; Dumitru et al., 2017). Finally, during calcite deposition, temperature dependent fractionation between drip water and calcite $\delta^{18} \mathrm{O}$ rarely follows theoretical estimations, hence the need for the determination of fractionation equations for each speleothem under consideration.

While drip water $\delta^{18} \mathrm{O}$ can be modified by evaporation inside the cave, another important environmental proxy, $\delta^{13} \mathrm{C}$, can be kinetically altered by strong degassing of $\mathrm{CO}_{2}$ from solution when the $p \mathrm{CO}_{2}$ gradient between drip water and cave atmosphere is large (Hendy, 1971; McDermott, 2004). $\mathrm{CO}_{2}$ concentration in cave air is generally a result of soil $\mathrm{CO}_{2}$ input, modulated by cave ventilation (Atkinson, 1977; White, 1988). Higher concentrations of dissolved $\mathrm{CO}_{2}$ are given by enhanced plant respiration and organic matter decomposition in the soil above the cave. Compared against cave air $\mathrm{CO}_{2}$, it helps identify variations in cave ventilation, and periods with increased calcite deposition or with increased kinetic fractionation of $\delta^{13} \mathrm{C}$ (Spötl et al., 2005; Banner et al., 2007; Mattey et al., 2010). Thus, a careful characterization of $p \mathrm{CO}_{2}$ gradients is an important element in cave monitoring. While cave air $\mathrm{CO}_{2}$ concentrations are easily measured and recorded using infrared technology, dissolved $\mathrm{CO}_{2}$ is usually modeled using the alkalinity and $\mathrm{pH}$ of water (Tooth and Fairchild, 2003; Spötl et al., 2005; Riechelmann et al., 2013). This approach is time consuming, costly, and offers only spot values.

Here we present the results of an ongoing monitoring study started in 2012 at Ascunsă Cave and, for comparison, at the nearby Isverna Cave. This study is designed to help us understand how climate information is archived by speleothems at Ascunsă Cave, in preparation for the publication of a series of new, high resolution stable isotope profiles from Holocene stalagmites from this cave and from several others in the Carpathian region.

Using isotopic analysis of rainfall, we try to identify the dominant vapor sources of precipitation, knowing that our region falls under the influence of both Atlantic and, to a lesser extent, Mediterranean air masses (Baltă and Geicu, 2008). Moreover, we want to detail the seasonal changes in precipitation $\delta^{18} \mathrm{O}$, in order to see to what extent the drip sites respond to seasonal variability. Further, we check whether modern calcite is deposited in equilibrium conditions or whether the isotopic values of oxygen and carbon are significantly modified by kinetic fractionation.

An important part of the present study was to develop and validate a new method for the more straightforward measurement of dissolved $\mathrm{CO}_{2}$ using air-water equilibrators and to open the way for high resolution data logging of drip water $\mathrm{CO}_{2}$ using infrared technology.

\section{Materials and methods}

Ascunsă Cave is situated in the Mehedinţi Mountains (southwestern Romania, Fig. 1), a region under a temperatecontinental climate with Mediterranean influences (Bojariu and Paliu, 2001; Apostol, 2008; Baltă and Geicu, 2008). The cave is $671 \mathrm{~m}$ long and $145 \mathrm{~m}$ deep, and its entrance is located at $1080 \mathrm{~m}$ above sea level (a.s.l.). This active cave, rich in speleothems, is developed mostly on the contact between wildflysch (mélange) and limestone. A small river enters the main cave passage at the White Chamber coming through the Tributary Passage, while the outside river was draining inside the cave through the entrance. At the moment, the outside river is redirected along the valley and does not enter the cave anymore. In 2012, a monitoring program was started and continuously developed at Ascunsă and Isverna caves, the latter situated at an altitude of $450 \mathrm{~m}$ a.s.l. and functioning as the main water collector of this karst system.

Inside Ascunsă Cave, several sites were equipped for monitoring (Fig. 2): POM Entr. (25 $\mathrm{m}$ from the entrance, $-7 \mathrm{~m}$ below the entrance level), POM A (100 m from the entrance, $-30 \mathrm{~m}$ ), POM 2 (220 $\mathrm{m}$ from the entrance, $-80 \mathrm{~m}$ ) and POM B $(270 \mathrm{~m}$ from the entrance, $-90 \mathrm{~m})$. Apart from these, we 


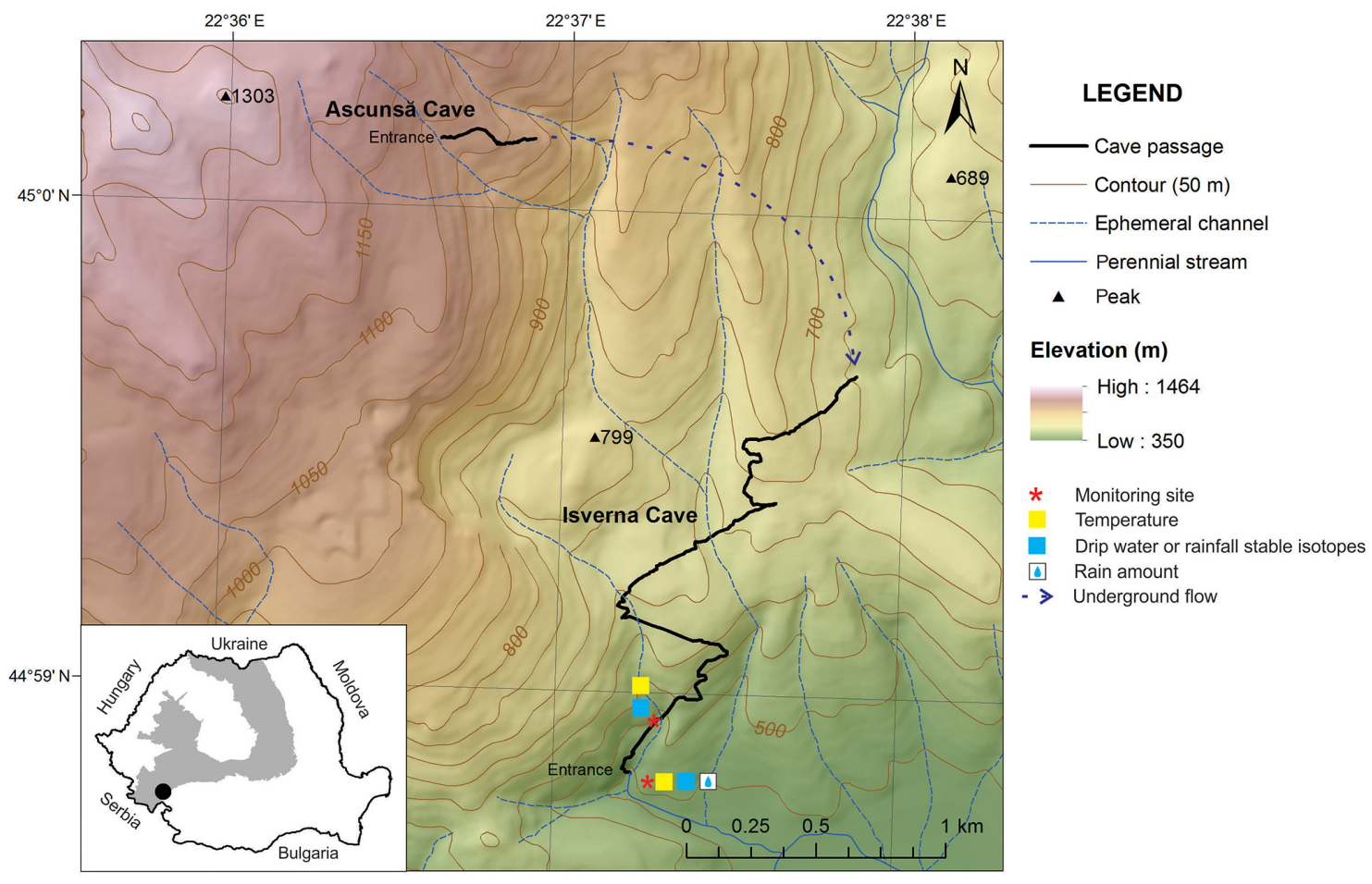

Figure 1. Location of Ascunsă and Isverna caves within the region.

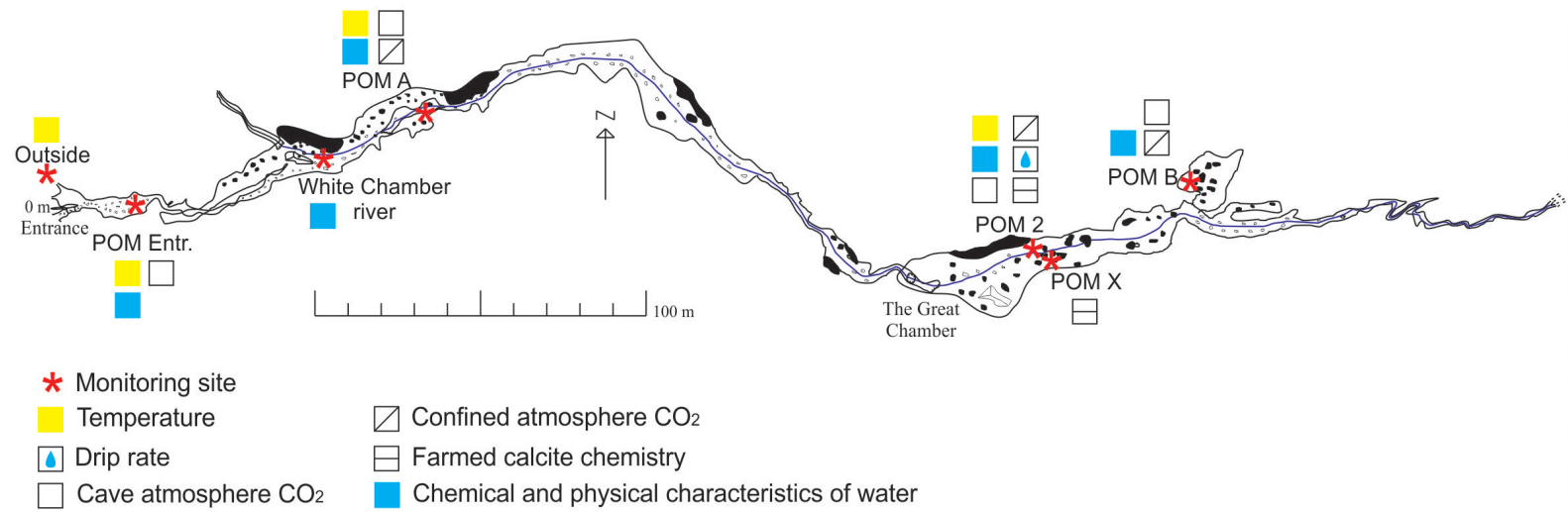

Figure 2. Map of Ascunsă Cave with the locations of the monitoring sites (below).

have also monitored the small river inside the cave, at a point close to POM A, as well as the outside temperature.

In Isverna Cave, a temperature logger was placed at $\sim 200 \mathrm{~m}$ from the entrance in the Intermediary Passage, sheltered from the possible influence of the large river flowing through the lower level of the cave. Air temperature, rainfall amount and the isotopic composition of precipitation were also monitored close to the cave ( $460 \mathrm{~m}$ a.s.l.). We note that due to local constraints we did not monitor outside temperature in standard siting conditions that are required from a meteorological station.

\subsection{Air temperature, relative humidity and drip counting}

Since 2014, Tinytag Plus2 temperature and relative humidity loggers as well as a Stalagmate drip counter have been added to the monitoring setup. The logger that records outside temperatures at Ascunsă Cave (POM Ext.) was first placed in a fissure in the entrance area and then moved in December 2014 a few meters outside into another fissure and covered with litter. For this reason, the temperature recorded by it is only an estimate for atmosphere values; however, it better reflects conditions at the surface-subsurface interface. 
Relative humidity (RH) in the two caves was difficult to measure for long periods of time. Condensing water vapor appears to saturate the sensors of data loggers; therefore, we would consider RH to be close to $100 \%$ at the two caves.

\subsection{Rainfall amount, rain water and drip water stable isotopes}

Rainfall amount was measured at Isverna (460 m a.s.l.) using a Pluvimate rainfall logger. It should be taken into account that the rainfall logger is not optimized to measure snowfall and can only measure the water produced by melting snow already present in its funnel. Monthly composite rain water samples were collected at Isverna and Drobeta-Turnu Severin meteorological station (located $40 \mathrm{~km}$ to the south, at 77 ma.s.l.) in $5 \mathrm{~L}$ volumes primed with white paraffin oil to prevent evaporation. Cave drip water was collected during each visit, at roughly $6-8$-week intervals, using $2 \mathrm{~mL}$ glass vials.

$\mathrm{H}-\mathrm{O}$ stable isotopes were measured in rainfall and drip waters using Picarro L2130i cavity ring-down spectroscopy systems. For the period July 2012-September 2013 they were measured at the Babeş-Bolyai University Stable Isotope Laboratory with a precision of $0.03 \%$ for $\delta^{18} \mathrm{O}$ and $0.1 \%$ for $\delta^{2} \mathrm{H}$. Reproducibility between measurements of duplicate samples was $\sim 0.08 \%$ of $\delta^{18} \mathrm{O}$ and $\sim 0.19 \%$ of $\delta^{2} \mathrm{H}$. All values are calibrated against VSMOW-SLAP.

Since September 2013 samples have been measured at the Ştefan cel Mare University Stable Isotope Laboratory using a Picarro L2130i, coupled to a high precision vaporizer. Samples were manually injected in the vaporization chamber and the average of the last four injections for which the standard deviation was better than 0.02 for $\delta^{18} \mathrm{O}$ and 0.2 for $\delta^{2} \mathrm{H}$ was used in calculating the isotopic values. The raw values were normalized to the SMOW-SLAP scale using two internal standards (and a third one used as a control), the precision being better than $0.02 \%$ for $\delta^{18} \mathrm{O}$ and $0.2 \%$ or $\delta^{2} \mathrm{H}$.

To investigate the possible vapor sources, we modeled the back trajectories of air masses that were present at our site during days with rainfall above $5 \mathrm{~mm}$. We ran the Hysplit 4 model (Draxler and Hess, 1997, 1998; Draxler, 1999; Stein et al., 2015) using the GDAS 0.5 data (DOC/NOAA/NWS/NCEP/EMC, 2001) for the coordinates of the pluviometer $\left(44^{\circ} 58^{\prime} 48.26^{\prime \prime} \mathrm{N}, 22^{\circ} 37^{\prime} 15.13^{\prime \prime} \mathrm{E}\right)$ at an altitude of $500 \mathrm{~m}$ above ground level.

\subsection{Cave air $\mathrm{CO}_{2}$}

During our monitoring program we measured $\mathrm{CO}_{2}$ concentration in the cave atmosphere at 6-8-week intervals. $\mathrm{CO}_{2}$ concentration was measured from July 2012 using two Vaisala GMP222 probes with an accuracy of $1.5 \%$ of range and $+2 \%$ of reading. Between July 2012 and December 2014 we used a probe calibrated for the range $0-2000$ (2k) ppm. From December 2014, a GMP 222 probe cali-

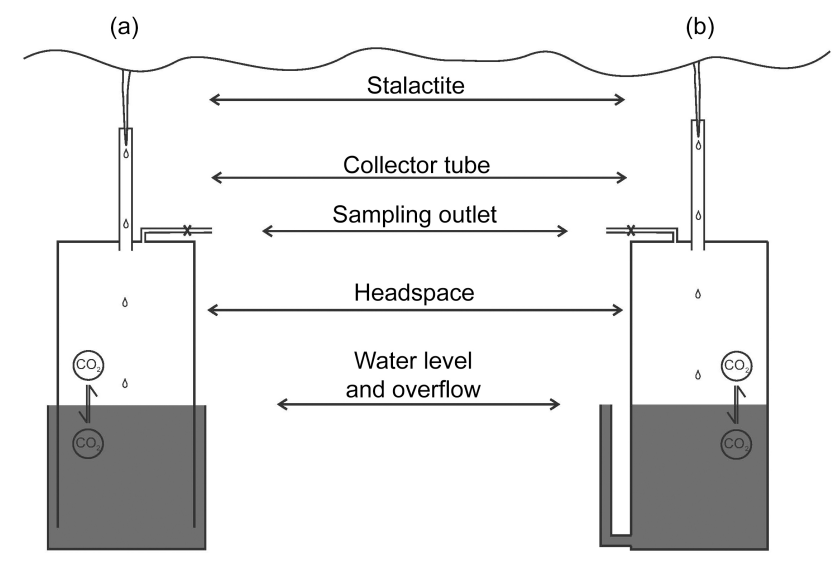

Figure 3. Schematic of the two water-air equilibrators used for the measuring of drip water $\mathrm{CO}_{2}$ : Type $\mathrm{A}(\mathbf{a})$ and Type $\mathrm{B}(\mathbf{b})$.

brated for the range 0-10000 (10k) ppm was used. Because in October 2014 we measured values as high as $3560 \mathrm{ppm}$, larger than the $2000 \mathrm{ppm}$ calibrated range of the probe, we ran a standardization experiment using the two probes. Following this test we saw that the $2 \mathrm{k}$ probe can confidently measure samples up to $3200 \mathrm{ppm}$. The errors associated with these figures are $221 \mathrm{ppm}$ for the $10 \mathrm{k}$ and $97 \mathrm{ppm}$ for the $2 \mathrm{k}$, giving us confidence that the field measurements are genuine.

\subsection{Drip water $\mathrm{CO}_{2}$}

To study drip water $p \mathrm{CO}_{2}$ we adapted the headspace method that is typically used to measure gases evolving from open waters or soils (see for example Broecker and Takahashi, 1966). Here we used two types of water-air equilibrators in which drip water was collected from stalactites via a tube and allowed to degas without having contact with the cave atmosphere (Fig. 3). Being isolated from the cave atmosphere, the $\mathrm{CO}_{2}$ concentration values of the confined atmosphere $\left(p \mathrm{CO}_{2 \mathrm{ca}}\right)$ are considered to be in equilibrium with those of the confined drip water $\left(p \mathrm{CO}_{2 \mathrm{cw}}\right)$, following Henry's law. The confined atmosphere evolved from degassing of the accumulated water was sampled and the concentration of $\mathrm{CO}_{2}$ was measured using a Vaisala GMP222 probe. As $\mathrm{CO}_{2}$ concentration values are affected by temperature and atmospheric pressure, these parameters were measured with a Vaisala HMP70 temperature probe and a barometer $( \pm 5 \mathrm{hPa}$ resolution). The concentration of $\mathrm{CO}_{2}$ in infiltrating waters $\left(\mathrm{CO}_{2 \mathrm{cw}}\right)$ was calculated using Henry's law, based on the values measured in the confined atmosphere of the equilibrator headspace $\left(\mathrm{CO}_{2 \mathrm{ca}}\right)$ and considering the solubility of $\mathrm{CO}_{2}$ in water $\left(\mathrm{H}^{\mathrm{cc}}=c_{\mathrm{cw}} / c_{\mathrm{ca}}\right)$ as 0.83 (Sander, 2015).

For the sampling itself, the GMP 222 probe was placed in a small volume attached to the equilibrator through a threeway closed valve. The probe volume was vacuumed using a manual vacuum pump also attached to the valve and, after checking the stability of the vacuum to ensure no leakage and 


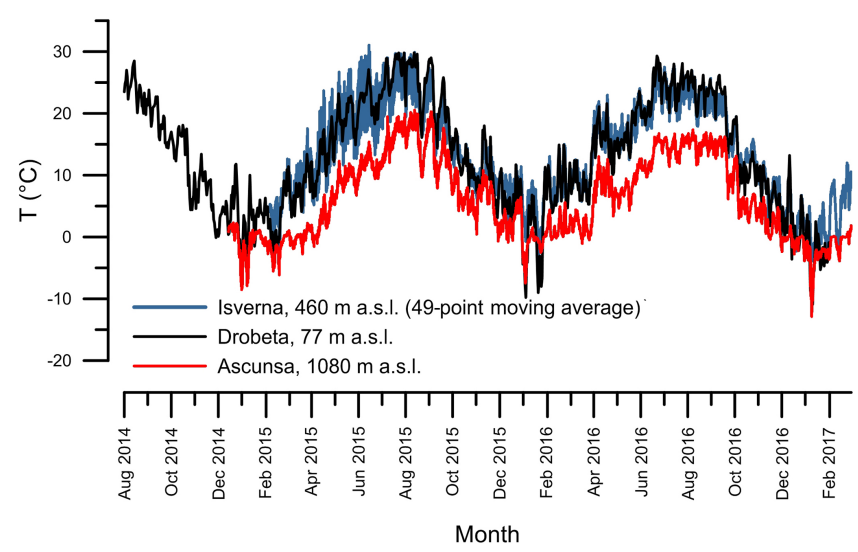

Figure 4. Temperature variability at Ascunsă Cave, Isverna and Drobeta. At Isverna the original data were logged at $30 \mathrm{~min}$ intervals and we smoothed the dataset using a 49-point moving average.

contamination with atmospheric air, the valve was opened to allow air from the headspace to enter the probe volume. Throughout this time the handheld meter was turned off. After allowing enough time for the air sample to penetrate the probe's membrane, the handheld meter was turned on.

The type A equilibrator (Fig. 3, left) is comprised of two main parts: an inner cylinder which is open at the base, and a slightly wider outer cylinder which is open at the top and hosts the inner cylinder. Water accumulated in the inner cylinder drains through its bottom and then flows upwards towards the rim of the outer one, where it drains. This ensures that water accumulated from drips has a large surface that is opened only to the interior of the inner cylinder and degasses towards the headspace. In order to reduce $\mathrm{CO}_{2}$ diffusion between cave air and the confined atmosphere through the accumulated water, the distance between the inner and outer cylinders has to be minimal, thus reducing the surface exposed towards the cave atmosphere. The rim height of the outer cylinder controls the height of the water table, and thus the headspace volume inside the inner cylinder. The headspace volume is important in relation to the sample quantity needed for the measurement, if the measurement is done on grab samples.

The type B equilibrator (Fig. 4, right) is simpler, accumulating water in a single volume and draining it through a tube mounted in its lower part. The upper level of this tube controls the water level inside the volume. In practice, we used a very long tube coiled around the exterior of the volume. The extended length of the tube has the role of hindering $\mathrm{CO}_{2}$ degassing towards the cave atmosphere, thus maximizing the likelihood that the confined atmosphere will remain in equilibrium with drip water.

When placing the equilibrators, care was taken in order for them to tap a stalactite with a drip rate high enough that would allow for the confined water to be constantly refreshed. Thus, we tried to reduce the danger of $\mathrm{CO}_{2}$ mobility through the whole water mass either towards or from the cave atmosphere.

At POM A we used a Type B equilibrator until November 2015, when we switched to Type A. Later, in November 2016, at POM B the Type B equilibrator was replaced with Type A.

\subsection{Water chemistry}

Drip water from the equilibrators described above, as well as water from nearby pools, were sampled from POM A, POM 2 and POM B. Using a WTW Sentix 41 electrode we measured the temperature and $\mathrm{pH}$ of cave waters, the latter after calibration with two buffer solutions with values of 7 and 10 that were left to equilibrate with the cave temperature. Electrical conductivity (EC) was measured using a WTW TetraCon 325 EC electrode. Total carbonate hardness was determined by titration using a Merck MColortest water hardness test.

Water samples collected during each visit were stored in Nalgene HDPE bottles. The complete chemical analysis of all water samples was conducted in the Hydrogeochemistry Laboratory of the Emil Racoviţă Institute of Speleology (Bucharest, Romania) on a Perkin Elmer NexIon 300S QICP-MS. All determinations were conducted in compliance with the US-EPA 6020B method (EPA, 2014). Calibrations were checked against NIST 1640a and NIST 1643e standard reference materials.

\subsection{Modern calcite stable isotopes}

Modern calcite was precipitated on glass plates and analyzed for $\mathrm{O}$ and $\mathrm{C}$ stable isotopes at the site of the published POM 2 stalagmite (Drăguşin et al., 2014) and on the top of the actively growing POM X stalagmite. Results for the period prior to April 2013 were reported by Drăguşin et al. (2014). Calcite farmed after this period was measured at CEA-CNRS-LSCE (France) on a VG-OPTIMA mass spectrometer. All values are reported in \%o relative to VPDB. The error is better than $0.08 \%$ for $\delta^{18} \mathrm{O}$ and $0.05 \%$ for $\delta^{13} \mathrm{C}$.

\subsection{Statistical methods}

In order to study the relationship between different parameters, we performed linear regression analysis using the least squares method and determined both the determination coefficient $\left(R^{2}\right)$ and its significance ( $p$ value).

The correlation between rainfall and drip rate was determined following the methodology described in Mangin (1984) and using the STOCHASTOS v3.0 software of d'Hulst (1994). 


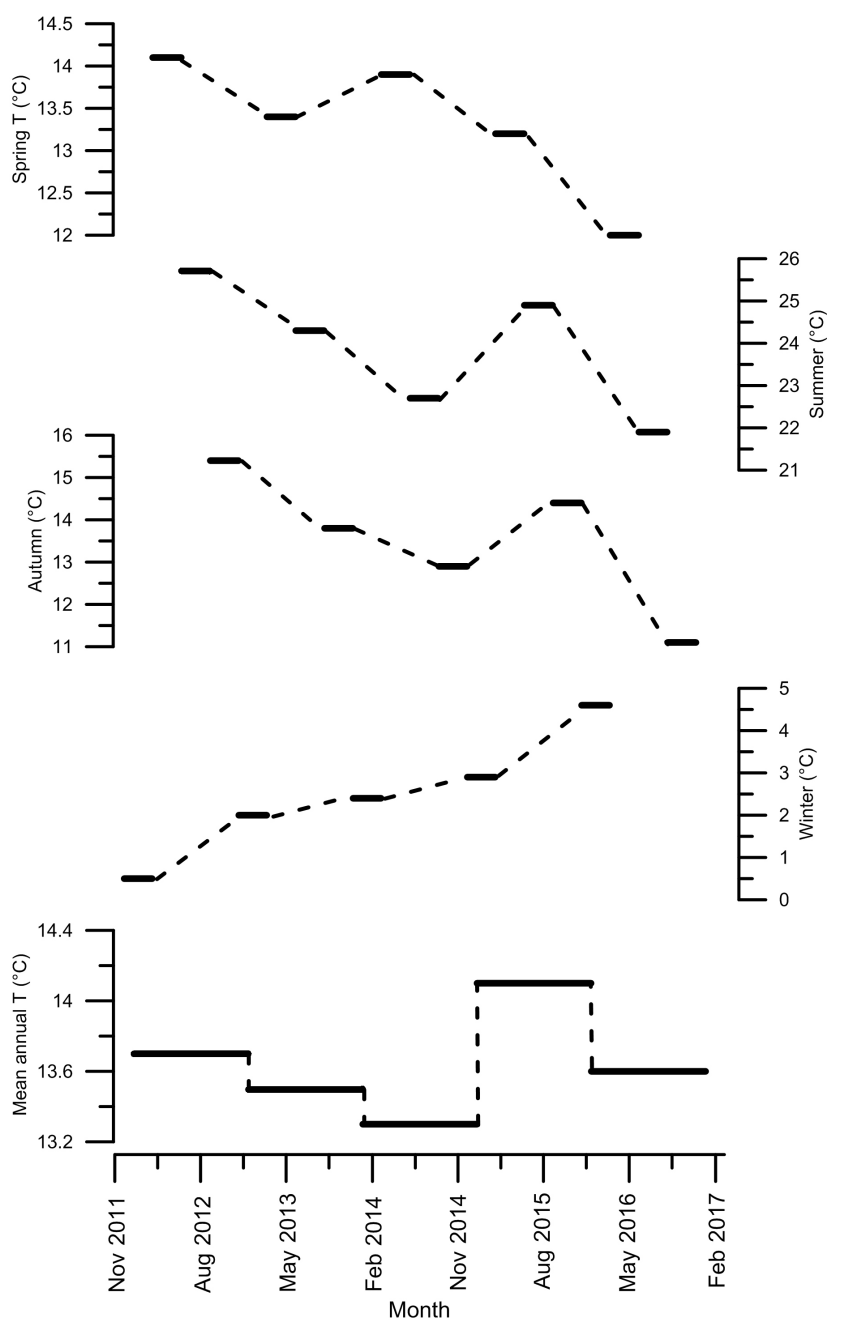

Figure 5. Annual and seasonal temperature averages at Drobeta since 2012.

\section{Results and discussion}

\subsection{Temperature regime of Ascunsă and Isverna caves}

For better comparison we use data logged continuously between February 2015 and February 2017 while all the logs overlap. The external temperature at the two caves has a good correlation, Ascunsă values showing lower daily amplitude, related probably to its subsurface location and being in a forested area. The mean value over this period was $6.77^{\circ} \mathrm{C}$ $\left(\mathrm{SD}=6.45^{\circ} \mathrm{C}\right)$ at Ascunsă and $14.01^{\circ} \mathrm{C}\left(\mathrm{SD}=7.70^{\circ} \mathrm{C}\right)$ at Isverna. Using temperature values from the European Climate Assessment (ECA; Klein Tank et al., 2002) for DrobetaTurnu Severin meteorological station (average $14.07^{\circ} \mathrm{C}$, $\mathrm{SD}=9.14^{\circ} \mathrm{C}$ ), we see that temperature variability in our area was similar to the regional one (Fig. 4).

Based on the good correlation between our site and the Drobeta meteorological station, we could use data from the latter in order to get more insight into the relative tem-

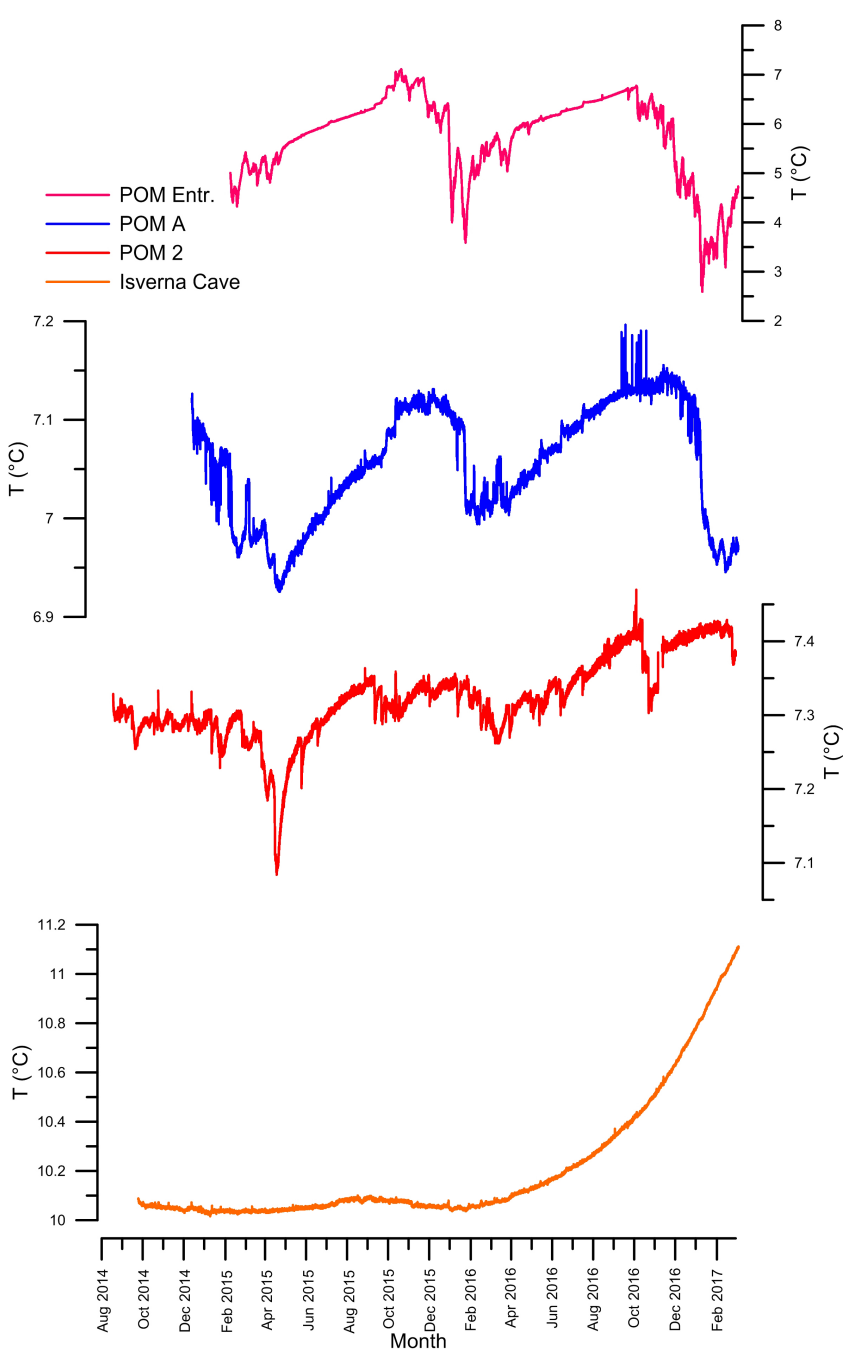

Figure 6. Temperature variability inside Ascunsă and Isverna caves.

perature variability over the whole monitored period at our site. Annual temperature at Drobeta decreased from an average of $13.7^{\circ} \mathrm{C}$ in 2012 to a value of $13.3{ }^{\circ} \mathrm{C}$ in 2014 , only to rise to $14.1^{\circ} \mathrm{C}$ in 2015 . In 2016 it dropped to $13.6^{\circ} \mathrm{C}$ (Fig. 5). At the seasonal scale, we see a more complex image. Average winter values increased constantly between 2012 $\left(0.5^{\circ} \mathrm{C}\right)$ and $2016\left(4.6^{\circ} \mathrm{C}\right)$, while spring temperatures generally decreased. Summer and autumn values were coupled, both showing a decrease between 2012 and 2014, a rise in 2015 , and a large drop in 2016, which resembles the variability of annual temperature. Thus, it appears that the summerautumn couple controls the annual temperature values.

At Ascunsă Cave, POM2 and POM A have a stable temperature regime (Fig. 6). While the average at $\mathrm{POM} 2$ is $7.33^{\circ} \mathrm{C}\left(\mathrm{SD}=0.06^{\circ} \mathrm{C}\right)$, at $\mathrm{POM} \mathrm{A}$ it is $7.05^{\circ} \mathrm{C}$ $\left(\mathrm{SD}=0.06^{\circ} \mathrm{C}\right)$. At the same time POM Entr. shows higher variability (average $5.74^{\circ} \mathrm{C}, \mathrm{SD}=0.86^{\circ} \mathrm{C}$ ) due to its proximity to the entrance and to the steep morphology of the passage, which allows cold air to easily reach this point. Such a 


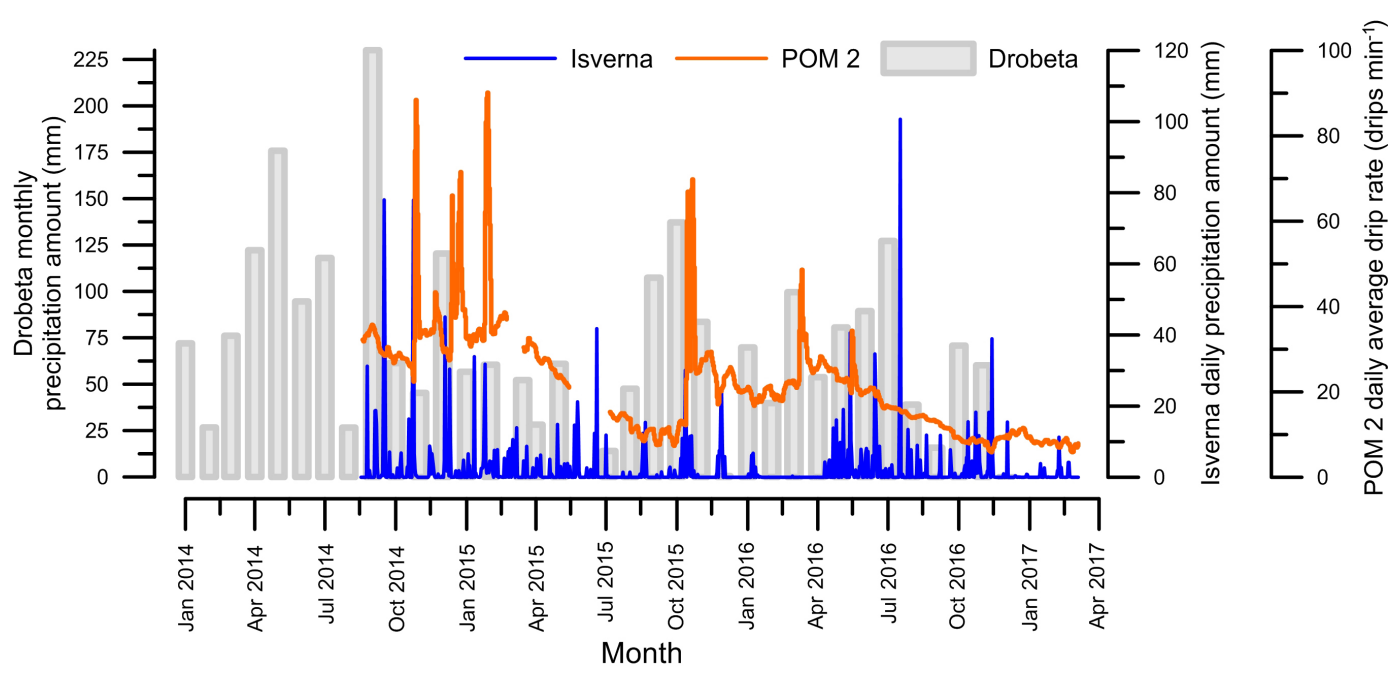

Figure 7. Comparison between monthly precipitation amount at Drobeta, daily precipitation amount at Isverna and POM 2 average daily drip rate.

dynamic behavior was described, for example, at Obir Cave (Austria) by Spötl et al. (2005). The resemblance between POM Entr. and POM A, with steady warming during summer and sharp decreases during late winter, shows that annual temperature variability is felt at POM A, but the amplitude is less than $0.2^{\circ} \mathrm{C}$. Because the variability at POM A and POM 2 is so small and would not affect any isotopic calculations that could be performed, we will not discuss it further.

Inside Isverna Cave the average temperature was $10.22^{\circ} \mathrm{C}$ $\left(\mathrm{SD}=0.25^{\circ} \mathrm{C}\right)$ between 2015 and 2017, with relatively stable conditions until February 2016. Temperature began to rise from $\sim 10.1^{\circ} \mathrm{C}$ in February 2016 to $\sim 11.1^{\circ} \mathrm{C}$ in March 2017. This disruption might reflect the 2015 warming recorded at the surface. As cave air temperature usually reflects long term mean annual values of surface air (Wigley and Brown, 1976) we can use the values from Isverna and Ascunsă caves to calculate a local lapse rate that should be taken into account when discussing the altitude effect on $\delta^{18} \mathrm{O}$. Given a $2.8^{\circ} \mathrm{C}$ difference between Isverna and Ascunsă (POM 2) for the relatively stable period of 2015-2016, we calculated a value of $6.1^{\circ} \mathrm{C} \mathrm{km}^{-1}$, in agreement with the global value of $6.4^{\circ} \mathrm{C} \mathrm{km}^{-1}$ (Brunt, 1933).

\subsection{Rainfall amount and drip rate variability}

According to data extracted from the ECA database (Klein Tank et al., 2002), the annual rainfall amount at Drobeta was unusually high in $2014(1169 \mathrm{~mm})$ in comparison to the 1961-2000 average of $662 \mathrm{~mm}$ (Dragotă and Baciu, 2008). Values decreased to $674 \mathrm{~mm}$ in 2015 and rose to $746 \mathrm{~mm}$ in 2016. At Isverna we recorded similar values for 2015 (702 $\mathrm{mm})$ and $2016(725 \mathrm{~mm})$.

Following the general trend in rainfall amount, drip rate values diminished over the recorded period, from $>30$ drips $\min ^{-1}$ at the beginning of the record to
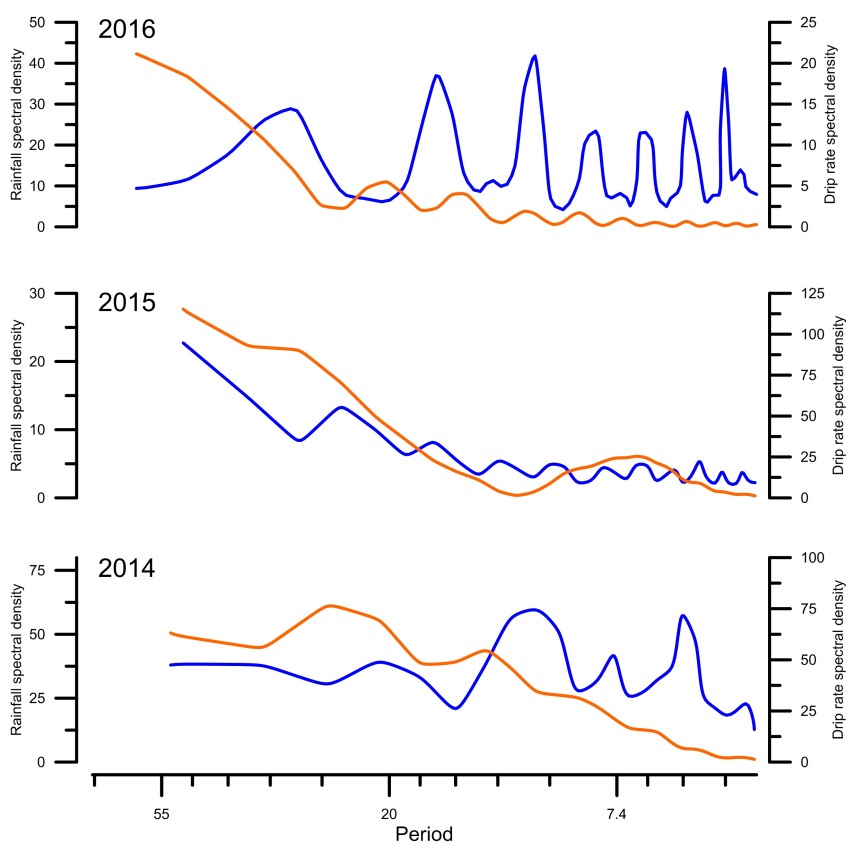

Figure 8. Results of the Fourier transform analysis of daily rainfall amount at Isverna and daily average drip rate at POM 2. For better visualization, the period axis is expressed in natural log and does not show values higher than 74 and lower than 4 .

8 drips $\min ^{-1}$ in early 2017 (Fig. 7). The higher drip rates recorded at the beginning of our study might reflect increased recharge from the previous months of 2014. During 20142015 , the time series is punctuated by sharp rises to values as high as 90 drips $\min ^{-1}$, linked to rainfall events (Fig. 3), a behavior that indicates a fracture recharge of the karst system (White, 2002; Ford and Williams, 2013). 
Although the drip log is not continuous, spectral analysis can help reveal how it responds to precipitation. We performed Fourier transform analysis of average daily drip rates and daily rainfall amounts on three continuous time slices: 18 August-30 November 2014, 5 July-30 November 2015, and 1 April-30 November 2016. The results show there is a close link between them for the period 2014-2015, while during 2016 there seems to be a weaker relationship (Fig. 8).

Cross-correlation analysis of the two datasets shows a similar picture: a very weak correlation in 2016 but a good correlation in 2014 and 2015. During the three periods analyzed, the strongest correlation is found 3 days after rainfall events. In 2014 and 2015 the $r_{k}$ values for a 3-day lag are similar ( 0.44 and 0.43 , respectively), while in 2016 it is only 0.07 (Fig. 9). Interestingly, during 2015 the analysis indicates a second peak in drip rate 8 days after rain events $\left(r_{k}=0.39\right)$. Based on these two peaks, we could speculate that the reservoir discharging through the POM 2 drip site might be fed, at times, via two routes: a fast one characterized by open fractures and a slower one possibly buffered by an epikarst reservoir (Mangin, 1994).

\section{3 $\mathrm{CO}_{2}$ concentration in cave air and drip water}

The variability of cave atmosphere $\mathrm{CO}_{2}\left(\mathrm{CO}_{2 \mathrm{~atm}}\right)$ at $\mathrm{POM}$ Entr. is in close relation to outside temperature $\left(R^{2}=0.66\right.$, $p$ value $<0.05$ ), reaching over $2500 \mathrm{ppm}$ during the warm season, but close to $500 \mathrm{ppm}$ in winter (Fig. 10). This might reflect a seasonal input of soil derived $\mathrm{CO}_{2}$ which is stronger in summer and weak during the cold season, combined with stronger winter ventilation (Wigley and Brown, 1976; Spötl et al., 2005; Banner et al., 2007). Air temperature at this site is between 5 and $7^{\circ} \mathrm{C}$ during summer, much colder that outside air, and between 4 and $6^{\circ} \mathrm{C}$ during winter, warmer than outside air. The winter setting could lead to stronger convective air circulation (Spötl et al., 2005; Fairchild and Baker, 2012), efficiently ventilating the entrance part of the cave. The winter mode is shorter than the summer one, covering the period November-December to March-April, and the transition between the two is sharp.

At the other three monitoring sites inside Ascunsă Cave, $\mathrm{CO}_{2 \text { atm }}$ records show similar trends: high values in October and low values in April. The $\mathrm{CO}_{2}$ concentrations vary between 700 and 2100 ppm over the period July 2012 to July 2014, but rose following the summer season of 2014 and reached a maximum of $4040 \mathrm{ppm}$ in March 2016. While the higher $\mathrm{CO}_{2 \text { atm }}$ recorded during 2014-2016 could be easily explained by enhanced biological activity following the temperature increase (Lloyd and Taylor, 1994), we cannot rule out a possible weakening ventilation.

Even though limestone thickness is different between the upper and lower parts of the cave (40 m at POM A and $100 \mathrm{~m}$ at POM 2 and POM B), the $\mathrm{CO}_{2 \text { atm }}$ signal remains the same. This striking resemblance could be due to similar transfer

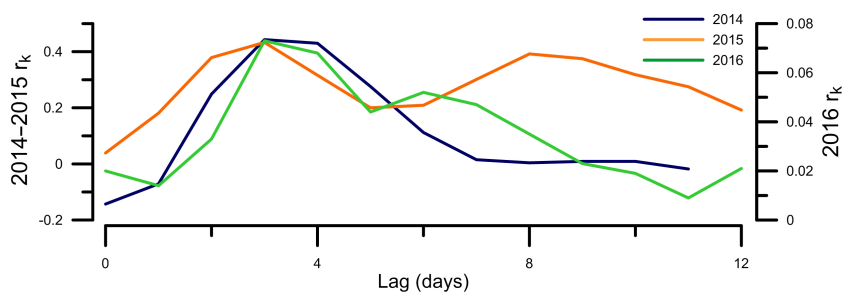

Figure 9. Cross-correlation coefficients between Isverna rainfall and POM 2 drip rate for the three periods analyzed. For better visualization, the 2016 values were plotted on a separate axis.

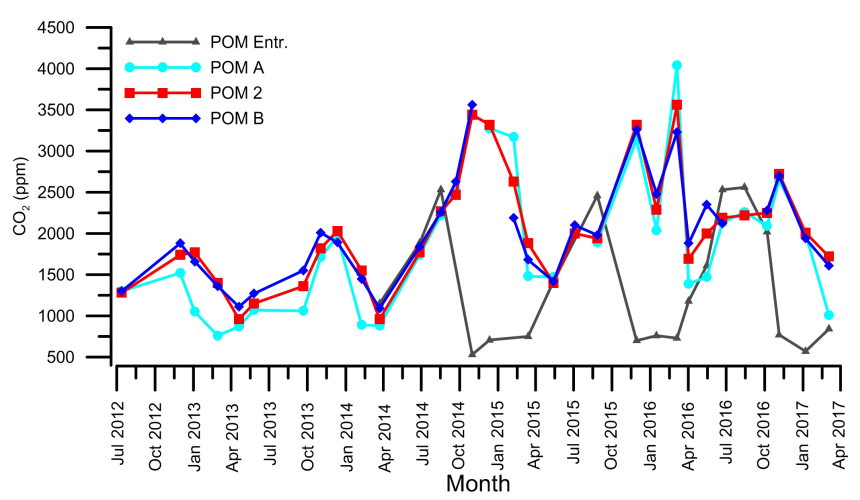

Figure 10. Cave air $\mathrm{CO}_{2}$ concentrations at Ascunsă Cave.

times of soil $\mathrm{CO}_{2}$ through the epikarst and karst and to similar ventilation processes throughout the cave.

Although the production of soil $\mathrm{CO}_{2}$ peaks in the warm season (Lloyd and Taylor, 1994; Breecker et al., 2012), the fact that we recorded the highest $\mathrm{CO}_{2 \mathrm{~atm}}$ values in winter could be explained by the existence of regions of $\mathrm{CO}_{2}$ production deep within the epikarst, as theoretically proposed by Atkinson (1977) and later recognized in different settings by Benavente et al. (2010), Mattey et al. (2010), Breeker et al. (2012), or Faimon et al. (2012). Recently, Noronha et al. (2015) used radiocarbon to trace the origin of speleothem carbon and suggested the possibility that this is dominated by carbon resulted from the decomposition of dissolved organic matter deep within the karst system. The existence at Ascunsă Cave of a deep seated carbon reservoir seems to be supported by the observation of a ventilation event in January 2016 which was expressed at all three inner sites as $\mathrm{a} \sim 1000 \mathrm{ppm}$ reduction in $\mathrm{CO}_{2}$ concentration following a drop of $10^{\circ} \mathrm{C}$ in outside air temperature. Together with the subsequent rise in values, this event implies the existence of a steady $\mathrm{CO}_{2}$ flux towards the cave, compatible with a winter production deep within the karst system.

In Fig. 11 we see that, with no exceptions, $\mathrm{CO}_{2 \mathrm{ca}}$ (and, by extension, $\mathrm{CO}_{2 \mathrm{cw}}$ ) was always greater than $\mathrm{CO}_{2 \mathrm{~atm}}$ by a few thousand ppm. Nevertheless, as opposed to $\mathrm{CO}_{2 \mathrm{~atm}}$, $\mathrm{CO}_{2 \mathrm{ca}}$ shows differences between the three sites. At POM $\mathrm{A} \mathrm{CO}_{2 \mathrm{ca}}$ has the highest values, reaching over $11000 \mathrm{ppm}$, close to theoretical concentrations in soil atmosphere (Atkin- 


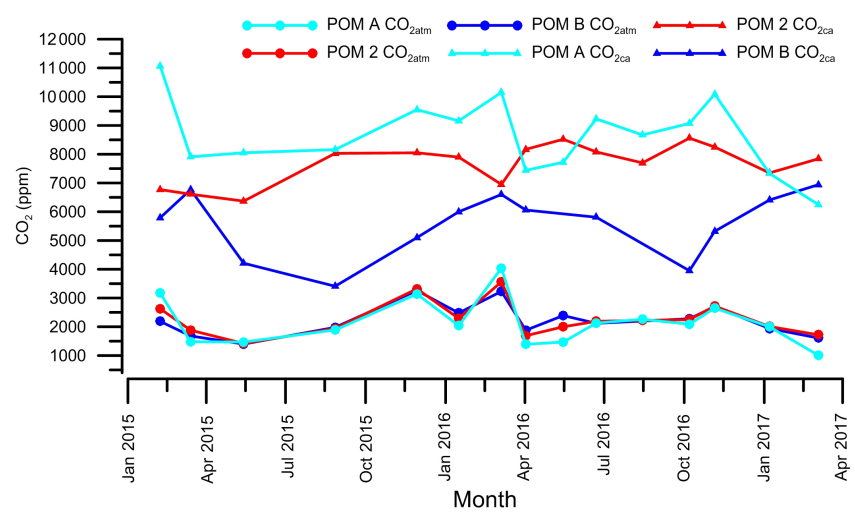

Figure 11. Measured concentrations of $\mathrm{CO}_{2}$ at Ascunsă Cave in the free atmosphere $\left(\mathrm{CO}_{2 \mathrm{~atm}}\right)$ and in the confined atmosphere of the equilibrators $\left(\mathrm{CO}_{2 \mathrm{ca}}\right)$.

son, 1977, and references therein; Brook et al., 1983), and shows a similar profile to $\mathrm{CO}_{2 \mathrm{~atm}}$. Supported by the resemblance between $\mathrm{CO}_{2 \mathrm{~atm}}$ and $\mathrm{CO}_{2 \mathrm{ca}}$ at POM A, we can state that the change in equilibrator type at POM A in November 2015 did not seem to affect the measured values of $\mathrm{CO}_{2 \mathrm{ca}}$. At POM $2 \mathrm{CO}_{2 \text { ca }}$ has slightly lower values, while POM B recorded the lowest values of the three points. This different behavior shows that the $\mathrm{CO}_{2}$ input via drip water is not similar throughout the cave and suggests that there are either different sources of $\mathrm{CO}_{2}$ feeding the system or different pathways toward these drip sites. The ventilation event of January 2016 appears to have slightly affected POM A CO $\mathrm{Ca}_{2 \mathrm{ca}}$ too, indicating that ventilation occurs to some extent on the $\mathrm{CO}_{2}$ pathway to this site.

The difference observed between $\mathrm{CO}_{2 \mathrm{cw}}$ and $\mathrm{CO}_{2 \mathrm{~atm}}$ is also seen between the modeled partial pressure in pool waters $\left(p \mathrm{CO}_{2} \mathrm{fw}\right.$ model $)$ that are considered to be in equilibrium with the cave atmosphere and the modeled $p \mathrm{CO}_{2}$ of the confined water $\left(p \mathrm{CO}_{2 \mathrm{cw} \text { model }}\right)$ calculated using the PHREEQC program (Fig. 12a). Nevertheless, the modeled values of the confined water are different, at times, from those based on the direct measurements ( $p \mathrm{CO}_{2 \text { cw measure }}$ Fig. $12 \mathrm{~b}$ ). This might be due to a range of uncertainties inherent from the different physical and chemical measurements of cave waters that were not considered here (e.g., the determination of hardness or alkalinity by titration or the determination of $\mathrm{pH}$ ). Using only the measured $p \mathrm{CO}_{2 \mathrm{ca}}$ to calculate $p \mathrm{CO}_{2 \mathrm{cw}}$ limits the intervening errors to just the straightforwardly known measurement error and to that associated with the empirical determination of Henry's law constant.

In support of the robustness of our method there are visible differences in other characteristics of the confined and pool waters. For example, the confined water is always more acidic (Fig. 13a). A clear difference is also seen in total carbonate hardness and electrical conductivity, with confined waters having always greater values in both parameters

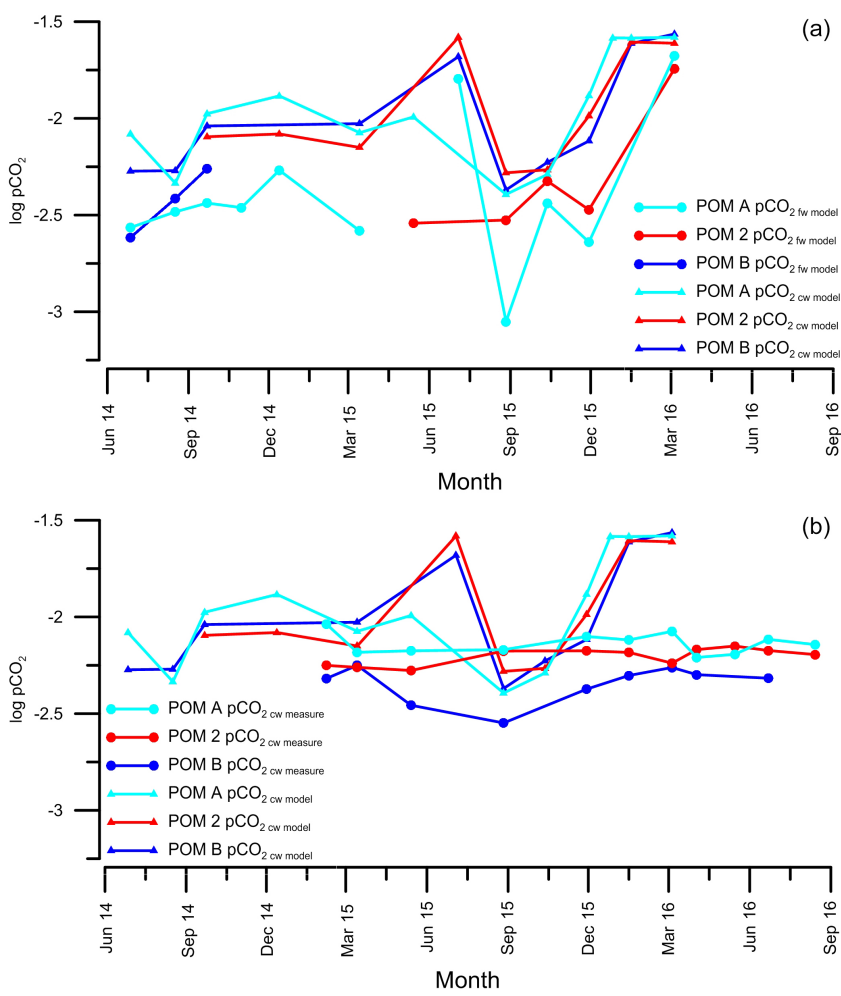

Figure 12. Comparison between (a) $\mathrm{CO}_{2} \mathrm{fw}$ model and $\mathrm{CO}_{2 \mathrm{cw} \text { model }}$ and (b) $\mathrm{CO}_{2 \mathrm{cw} \text { model }}$ and $\mathrm{CO}_{2 \mathrm{cw} \text { measure }}$.

(Fig. 13b and c). These differences could be explained by the higher content of dissolved $\mathrm{CO}_{2}$.

\subsection{Rain and drip water stable isotopes}

\subsubsection{Rainfall isotopic signature}

At Isverna, between September 2014 and June 2016, $\delta^{18} \mathrm{O}$ values in precipitation show seasonal variability, between a minimum of $-14.68 \%$ in January 2016 and a maximum of $-4.75 \%$ in April 2015 (Fig. 14). The weighted average $\delta^{18} \mathrm{O}$ and $\delta^{2} \mathrm{H}$ values of January-December 2015 are -9.36 and $-62.09 \%$, comparable to weighted annual means derived from GNIP (IAEA/WMO, 2016). During 2015, weighted averages at Drobeta were -8.31 and $-53.56 \%$, respectively. These values are consistent with those measured by Bojar et al. (2017) at Dumbrava, some $60 \mathrm{~km}$ southeast of Isverna.

The local meteoric water line (LMWL) at Isverna is defined as $\delta^{2} \mathrm{H}=7.7 \delta^{18} \mathrm{O}+9.7$, for January-December 2015, and $\delta^{2} \mathrm{H}=7.7 \delta^{18} \mathrm{O}+10.1$ for September 2014 to June 2016, an equation similar to the global meteoric water line (GMWL; Craig, 1961). At Drobeta, the 2015 LMWL is defined as $\delta^{2} \mathrm{H}=7.9 \delta^{18} \mathrm{O}+9.5$ and deuterium excess values varied between 4 and 16\%o (Fig. 15a).

While we would expect a Mediterranean contribution to precipitation brought via the winter cyclones (Bojariu and Paliu, 2001), the LMWL equation seems to indicate the At- 

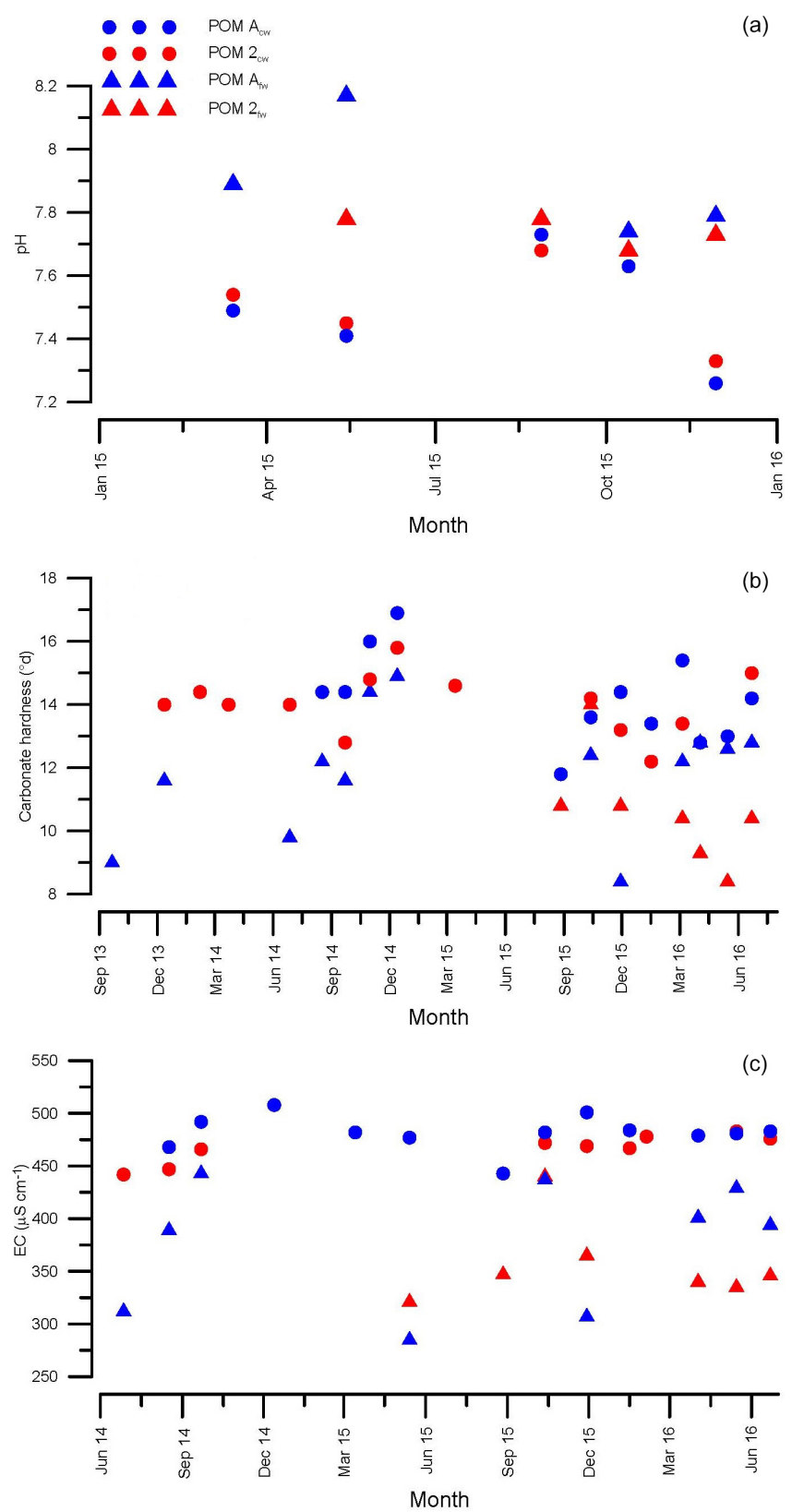

Figure 13. Comparison between pool and confined waters: (a) $\mathrm{pH}$, (b) carbonate hardness and (c) electrical conductivity.

lantic Ocean as a heavily dominating vapor source. Knowing that the equation of the Mediterranean meteoric water line is $\delta^{2} \mathrm{H}=8 \delta^{18} \mathrm{O}+22 \%$ (Gat and Carmi, 1987), any mixing of the two sources would modify the LMWL.

The deuterium excess values fall between 11 and $15 \%$, outside the range predicted by GNIP and characteristic of a region with enhanced evaporation (Dansgaard, 1964; Gat et al., 2003; Delattre et al., 2015). At Dumbrava (Bojar et al., 2017) and Drobeta they have similar values and variability (Fig. 15b), indicating a regionally consistent setting.

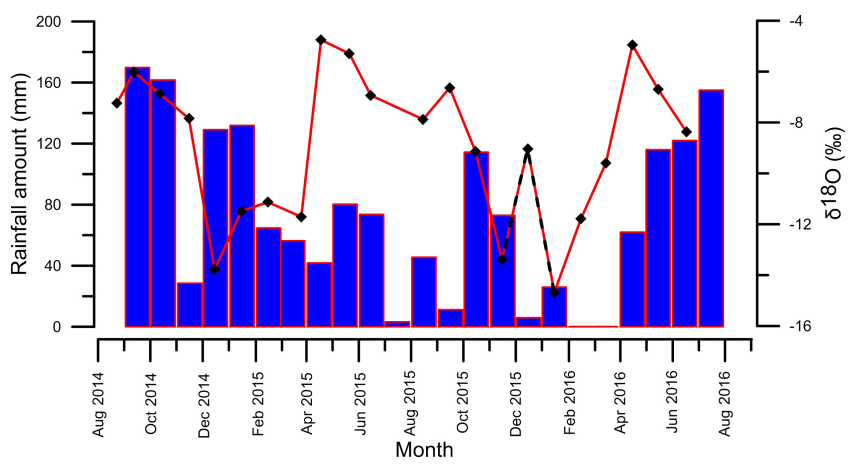

Figure 14. Monthly rainfall amounts and $\delta^{18} \mathrm{O}$ values at Isverna. The red-black line highlights the anomalous character of the December 2015 isotopic value.

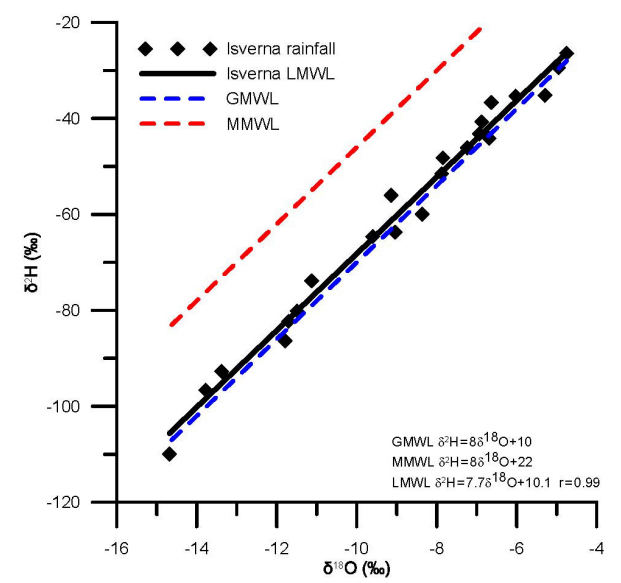

(a)

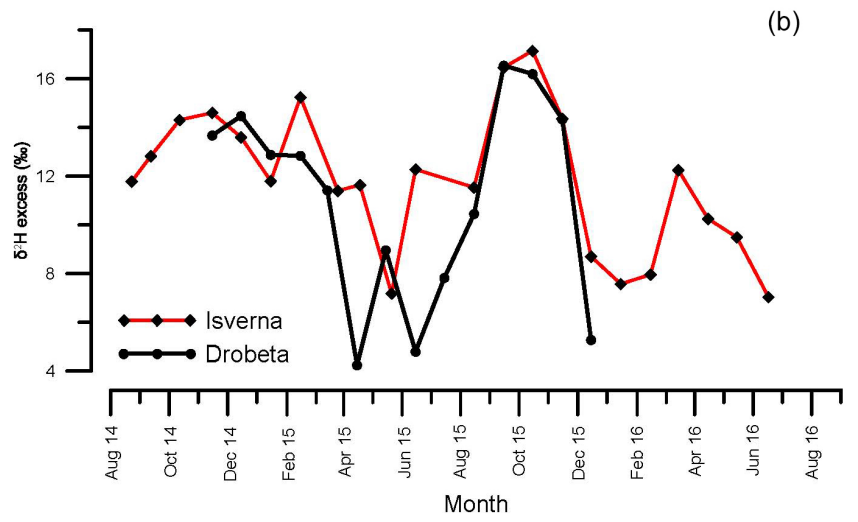

Figure 15. Comparison of the (a) GMWL (Craig, 1961), MMWL (Gat and Carmi, 1970) and LMWL and (b) deuterium excess values at Isverna and Drobeta.

Between August 2014 and August 2016 there were 104 rainy days with at least $5 \mathrm{~mm}$ of rain and we modeled the 5-day back trajectories of the air masses present at our site during these days (Fig. 16). These trajectories appear to fall within four categories: Atlantic, Mediterranean, eastern European/western Asian and a more local one, not spreading much outside the Carpathian-Balkan region. Nevertheless, it 


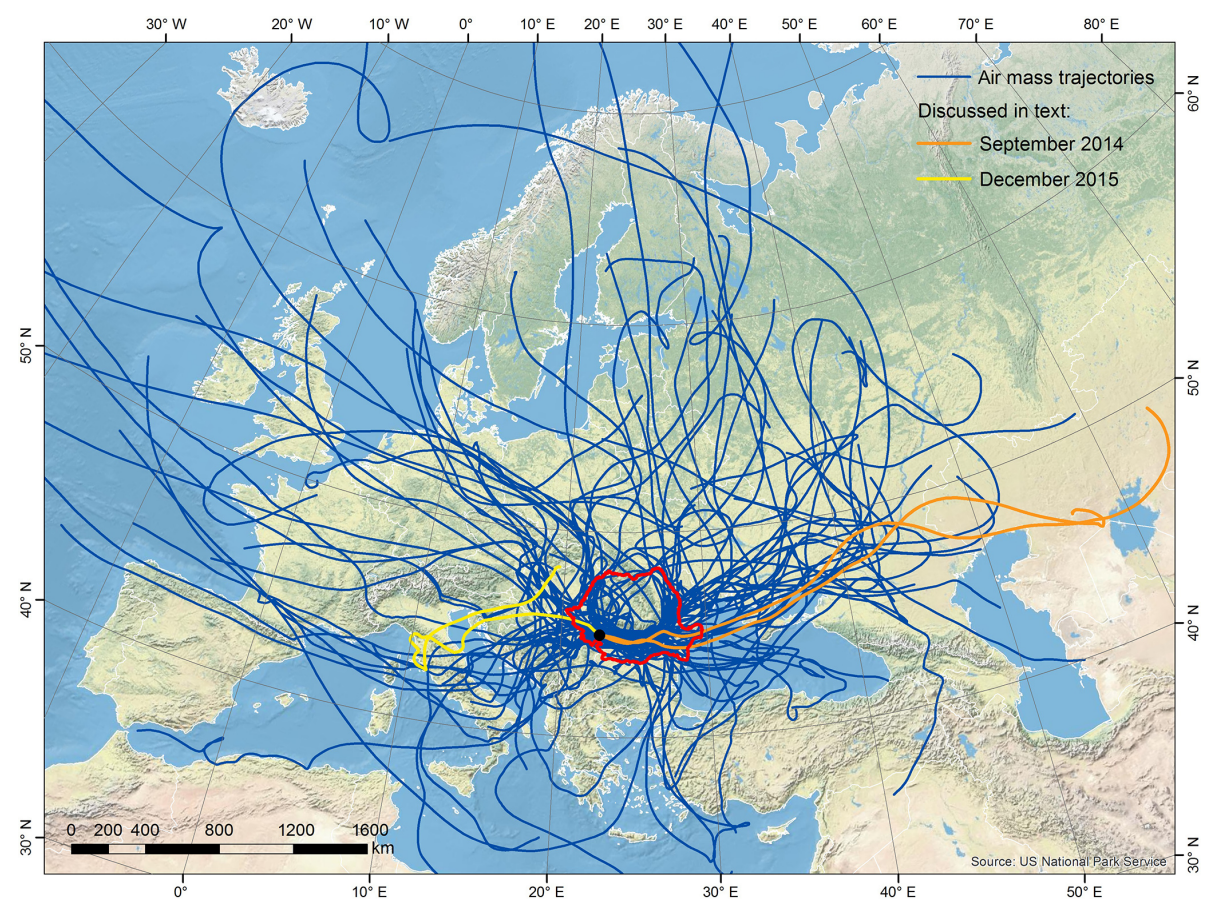

Figure 16. Air mass trajectories reconstructed using the Hysplit 4 model.

can be seen that some of the eastern European trajectories are in fact deflections of Atlantic pathways. Thus, the majority of the air masses arriving at our site during rainy days appears to be of Atlantic origin, with only a restricted number originating or passing over the Mediterranean. As the origin of an air mass is not definitive evidence of the origin of moisture that condensed when it arrived at a site, it is still an indication of the vapor source. We note that it is not within the scope of this paper to detail the exact moisture content of each air mass whose trajectory we modeled, but that it should be the aim of further study. As we see that the Mediterranean was a minor contributor to local precipitation, the evaporative component implied by the deuterium excess could indicate that rainfall included an important element of recycled moisture over the European land mass (Aemisegger et al., 2014).

In December 2015 an unusually high $\delta^{18} \mathrm{O}$ value of $-9.04 \%$ was recorded. Throughout the whole month, we recorded a single rain episode of $6 \mathrm{~mm}$ on 1 December 2015 . This event started in the afternoon when the air temperature was $12^{\circ} \mathrm{C}$ and ended at midnight when temperatures were still as high as $9^{\circ} \mathrm{C}$. The air mass present at our site during this day appears to have travelled through central Europe, across the Adriatic and into the Tyrrhenian Sea, from where it returned to mainland Europe. This complicated pathway makes the air mass prone to accumulating both continental and Mediterranean moisture. We suggest that the high isotopic value is also linked to the abnormally high air temperature for this season that promoted higher continental evaporation and is not representative of seasonal variability.

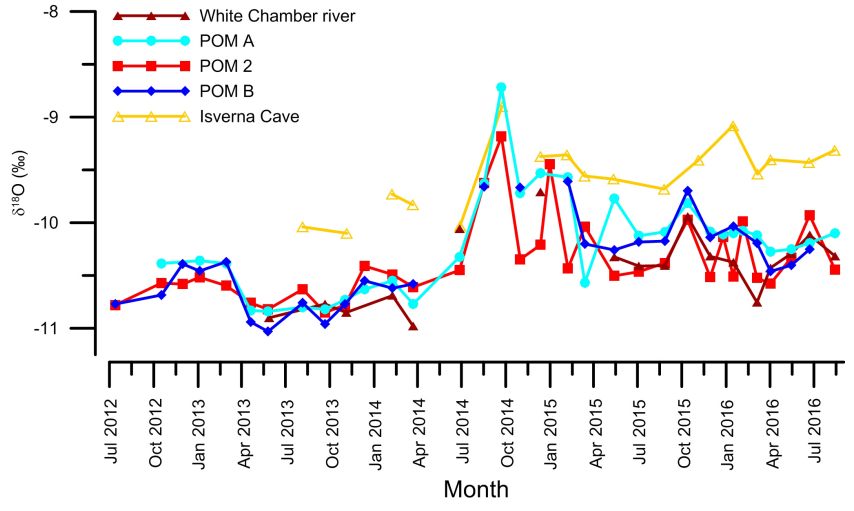

Figure 17. Drip water $\delta^{18} \mathrm{O}$ variability at Ascunsă and Isverna caves.

\subsubsection{Drip water stable isotopes}

At Ascunsă Cave drip water $\delta^{18} \mathrm{O}$ shows almost the same variability at all sites (Fig. 17), but with a muted signal when compared to that of rain water, an indication of a well-mixed aquifer (Riechelmann et al., 2011; Smith et al., 2014). A similar variability is seen in drip water at Green Lake in Isverna Cave too, although here the values are higher, an expected result of the altitude effect. This gives us confidence that this signal at Ascunsă Cave is not site related and that it is indeed representative of the surrounding area. Drip water $\delta^{18} \mathrm{O}$ at the two caves rose in the summer of 2014. For example, at POM2 the 2012-2014 average $\delta^{18} \mathrm{O}$ was $-10.65 \%$, whereas 

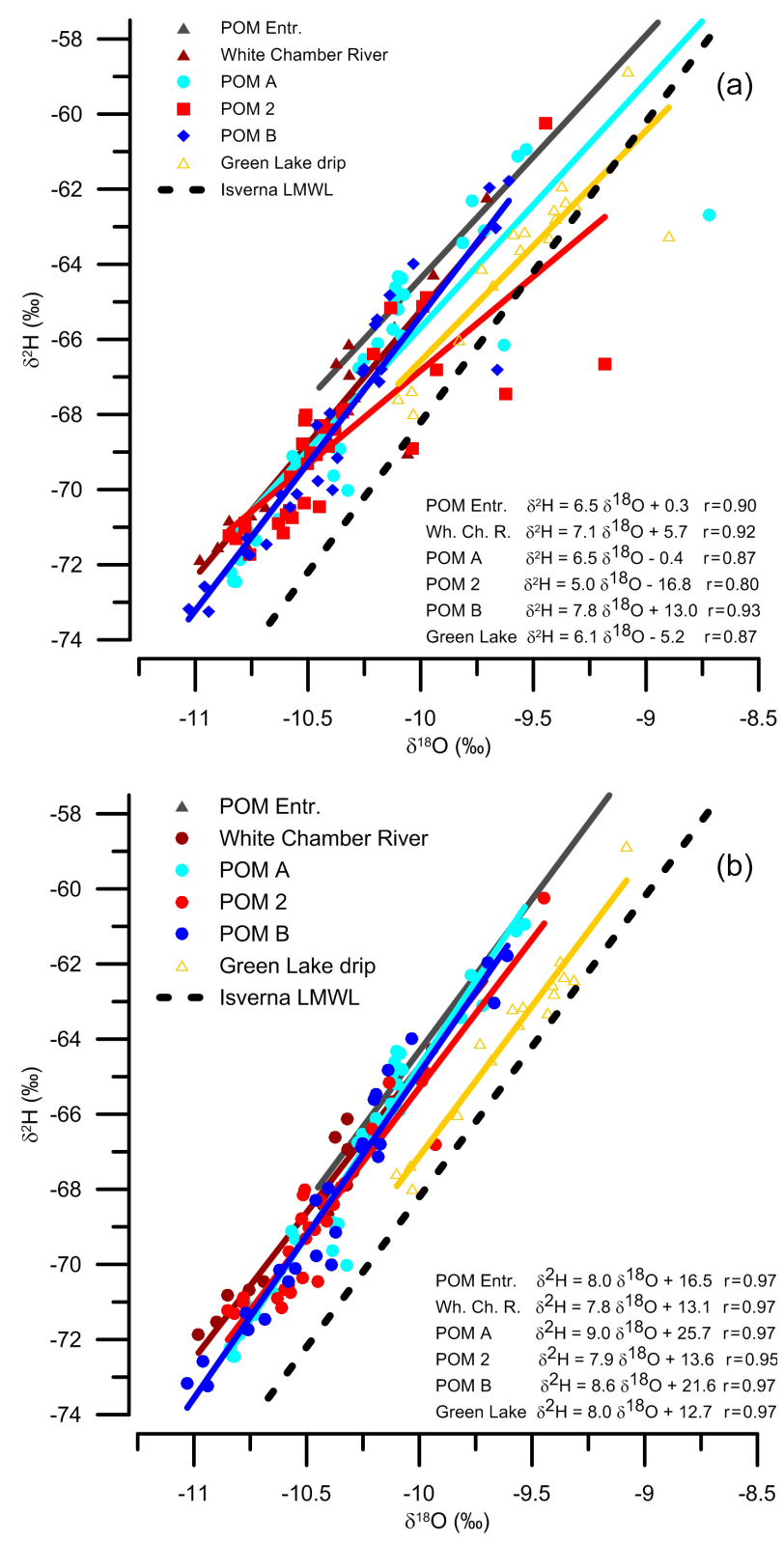

Figure 18. Water lines of drip points from Ascunsă and Isverna caves compared to the Isverna LMWL for the whole monitoring period (a) and after discarding anomalous values (b).

the following period had an average of $-10.19 \%$. Here, the 2012-2016 water line is defined as $\delta^{2} \mathrm{H}=5.0 \delta^{18} \mathrm{O}-16.8$ (Fig. 18a). For the period August 2013-August 2016, drip water at Green Lake in Isverna Cave has a water line defined as $\delta^{2} \mathrm{H}=6.1 \delta^{18} \mathrm{O}-5.2$ and deuterium excess values around 12-13\%o, with an exception in September 2014, when we recorded $7.95 \%$.

The September 2014 values and, at other drip sites, those from August 2014 too, have an outlier character in both $\delta^{18} \mathrm{O}$ and $\delta^{2} \mathrm{H}$. On 17 August 2014 we measured values as high as $-9.62 \%$ at POM 2, while on 17 September 2014 we measured $-9.18 \%$. Compared to the whole deuterium excess record at POM 2 which runs between 13 and $16 \%$, their values stand out for being very low $(9.5$ and $6.8 \%$, respectively). Such anomalous values, recorded at all drip sites, appear to be linked to the advection of air masses from around the Caspian Sea (Fig. 16). For that region, the weighted August and September $\delta^{18} \mathrm{O}$ values stand between -6 and $-2 \%$ and the weighted deuterium excess around 0 (IAEA/WMO, 2016). An enriched moisture source would explain both the $\delta^{18} \mathrm{O}$ and deuterium excess values recorded during these events. After discarding the enriched values of August and September 2014 but also those of March 2015, the ground water line (GWL) at POM 2 is $\delta^{2} \mathrm{H}=7.9$ $\delta^{18} \mathrm{O}+13.6$ and deuterium excess values fall between 13 and 15.5\% . At Green Lake, after discarding the September 2014 values, the GWL becomes $\delta^{2} \mathrm{H}=8.0 \delta^{18} \mathrm{O}+12.7$.

The September 2014 event, with $\delta^{18} \mathrm{O}$ values as high as $-8.72 \%$, is replicated in both caves, and follows a high intensity precipitation episode that took place a week prior. At Drobeta it peaked at a total of $157 \mathrm{~mm}$ on 14 and 15 September 2014 (Klein Tank et al., 2002), while at Isverna we recorded $104 \mathrm{~mm}$ during these 2 days. The study of these two rain events and their reflection in the cave is interesting from two points of view: first of all it indicates that the transfer time of water from the surface to the cave is on the order of days, as also indicated by drip rate response to rainfall. Secondly, the lack of any strong peaks in the drip log at this time could be attributed to the fact that these events did not contribute too much to reservoir recharge, or that some of the signal was buffered by the epikarst. At POM 2, a declining trend in drip rate was present before the September event, probably associated with summer drought. On 18 September 2014, 3 days after the rain event, the drip rate started to rise from 28 drips $\mathrm{min}^{-1}$ and peaked 2 days later at only 31 drips $\min ^{-1}$. For comparison, a rain event from 22 to 23 October 2014 totaling $116 \mathrm{~mm}$ produced a rise in drip rate from 21 to 90 drips $\mathrm{min}^{-1}$. This was followed by a long period when drip rates remained above 30 drips $\mathrm{min}^{-1}$.

After discarding the August-September 2014 values, we recalculated the groundwater lines from our drip sites and compared them to the LMWL. From Fig. 18b we can see that they all have intercept values above 10 . This could be due to processes that take place after the precipitation reaches the ground, most probably evaporation in the soil/epikarst as observed for example in semi-arid regions by Bar-Matthews et al. (1996) or Markowska et al. (2016). We can also see that the GWL at Green Lake inside Isverna Cave is closest to the Isverna LMWL, while all of Ascunsă Cave plots the highest.

\subsection{Farmed calcite stable isotopes}

Average $\delta^{18} \mathrm{O}$ values of farmed calcite at POM $2(-8.07 \%$ ) and POM X $(-7.88 \%$ ) show similar variability throughout the monitored period, with the POM X samples having, 


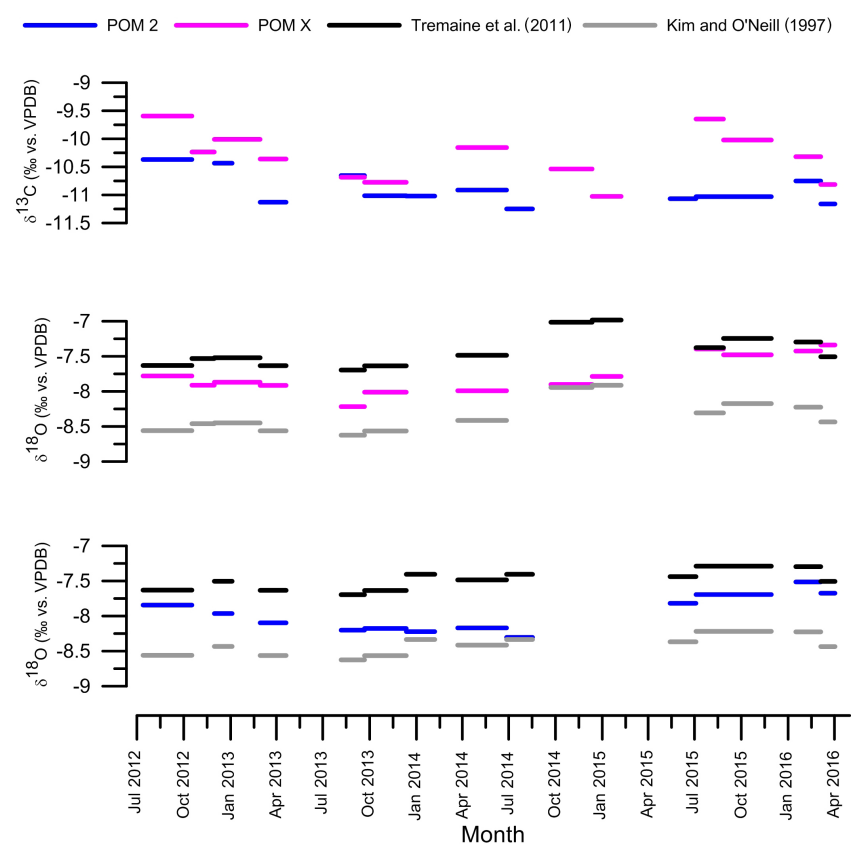

Figure 19. Stable isotope values of calcite farmed at POM 2 and POM X.

in general, higher values (Fig. 19). A large difference between drip water and cave atmosphere $p \mathrm{CO}_{2}$, as determined at Ascunsă Cave, is a prerequisite for out of equilibrium processes (Hendy, 1971). A slower drip rate, as observed at POM X in comparison to POM 2, would promote longer degassing times, thus increasing the kinetic effects and leading to higher calcite isotopic values (Dreybrodt, 2008). Using the equations of Kim and O'Neil (1997) and Tremaine et al. (2011) we calculated the theoretical $\delta^{18} \mathrm{O}$ equilibrium values of the farmed calcite at POM 2 and POM X, at $7.2^{\circ} \mathrm{C}$. The input value for drip water $\delta^{18} \mathrm{O}$ was considered as the average of samples bracketing the farming period. The measured $\delta^{18} \mathrm{O}$ values plot above the Kim and O'Neil (1997) predictions and below those predicted by the equation of Tremaine et al. (2011).

For the deposition period June-August 2014 we used only the drip water $\delta^{18} \mathrm{O}$ value at the beginning of the deposition interval and not the average of the samples bracketing the whole period, as the enriched drip water from August 2014 would predict an unreasonable value of $-6.77 \%$ o $-7.70 \%$.

The POM X $\delta^{13} \mathrm{C}$ values appear to be affected too by the slow drip rate and the increased kinetic fractionation that accompanies it. The values are higher than at POM2 and more variable. When compared to the available drip rate recorded at POM2, we see that two low $\delta^{13} \mathrm{C}$ values $(-10.54$ and $-11.03 \%$ ) occur during periods with average drip rates of 33 and 43 drips $\min ^{-1}$, respectively (September/December 2014 and December 2014-February 2015), while a third one $(-9.65 \%$ ) was measured from a period with an average of 13 drips min $^{-1}$ (July-August 2015).

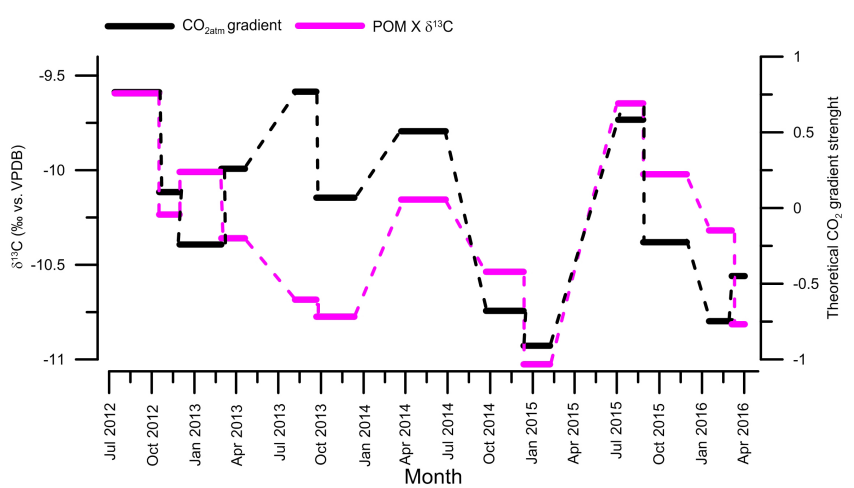

Figure 20. POM $\mathrm{X} \delta^{13} \mathrm{C}$ variability and its relationship with degassing gradients.

Moreover, when POM X $\delta^{13} \mathrm{C}$ values are compared with average air temperatures from Drobeta (ECA dataset, Klein Tank et al., 2002), there seems to be a good correlation between the two, except for two periods: November 2012February 2013 and August-September 2013. If these two samples are omitted from the calculation, the value of $R^{2}$ is 0.74 ( $p$ value $<0.05)$. We note that we also calculated the precipitation amount for the same periods and their correlation with $\delta^{13} \mathrm{C}$ or $\delta^{18} \mathrm{O}$ is weaker: $R^{2}=0.06$ ( $p$ value $\left.>0.05\right)$ for $\delta^{13} \mathrm{C}$ and 0.35 ( $p$ value $>0.05$ ) for $\delta^{18} \mathrm{O}$. The same test was applied for POM2 farmed calcite and it returned an $R^{2}$ value of 0.05 ( $p$ value $>0.05$ ) for $\delta^{13} \mathrm{C}$ and 0.14 for $\delta^{18} \mathrm{O}(p$ value $>0.05)$.

A direct correlation between calcite $\delta^{13} \mathrm{C}$ and outside air temperature is counterintuitive, as common knowledge states that warmer periods are characterized by lower calcite values due to the input of more depleted $\delta^{13} \mathrm{C}$ via organic activity (see for example the review of McDermott, 2004). Such a direct correlation could be induced by a full seasonal delay in the transfer time of the surface signal, but this is contradicted by the common variability of $\delta^{18} \mathrm{O}$ at both POM 2 and POM X. Besides, as this $\delta^{13} \mathrm{C}$ anomaly is not replicated at POM 2, it could mean that it is a process specific to POM X. A likely explanation would be that it is the result of kinetic fractionation during periods with increased $p \mathrm{CO}_{2}$ gradients between drip water and cave atmosphere, a process further enhanced by low drip rates (Mattey et al., 2010, 2014). Assuming that higher air temperature is transposed into higher drip water $\mathrm{CO}_{2}$ via increased organic activity, we calculated, for the periods with available $\delta^{13} \mathrm{C}$ data, average air $\mathrm{CO}_{2}$ at POM 2 as well as the average temperature values from Drobeta. Further, we normalized the resulting values and subtracted $\mathrm{CO}_{2}$ from temperature. We then plotted the resulting values in Fig. 20, considering that larger differences represent steeper $\mathrm{CO}_{2}$ gradients between drip water and air, while lower differences represent gentler gradients. We can see that there is good correlation between the two datasets, except for the periods November 2012-February 2013 and August- 
September 2013. If these two samples are omitted from the calculation, the value of $R^{2}$ is 0.54 ( $p$ value $<0.05$ ).

\subsection{Relevance for speleothem paleoclimate studies}

Rainfall isotope data presented here show that Ascunsă Cave and its surroundings are nowadays mostly influenced by recycled Atlantic moisture, with a reduced Mediterranean contribution. Nevertheless, by analyzing $\delta^{18} \mathrm{O}$ data from stalagmite POM 2, Drăguşin et al. (2014) demonstrated that this stalagmite recorded during the Holocene millennial scale hydrological changes that took place in the eastern Mediterranean. This suggests that calcite at Ascunsă Cave is continuously deposited under different climate settings, thus making speleothems from this cave useful for the study of past atmospheric circulation (Cruz et al., 2006; Lachniet, 2009). Moreover, the stable microclimate conditions inside the cave indicate that $\delta^{18} \mathrm{O}$ values of speleothems are not kinetically altered and are representative of surface climate conditions (Baldini et al., 2006; Dreybrodt and Scholz, 2011).

At the same time, when the difference between drip water and cave air $p \mathrm{CO}_{2}$ is coupled with slow drip rates, it can induce important changes in calcite $\delta^{13} \mathrm{C}$ through degassing (Dreybrodt and Scholz, 2011; Riechelmann et al, 2013), as we saw in the case of stalagmite POM X. While POM 2 and POM X have similar $\delta^{18} \mathrm{O}$ behaviors, POM X $\delta^{13} \mathrm{C}$ might prove helpful in extracting information on the past kinetic fractionation strength and its controls: cave air $\mathrm{CO}_{2}$ /ventilation and drip water $\mathrm{CO}_{2}$ /outside temperature.

\section{Conclusions}

We presented here the characteristics of a series of chemical and physical parameters recorded in air, water and modern calcite at Ascunsă and Isverna caves, as a prerequisite for speleothem paleoclimate proxy calibration.

Carbon dioxide levels in cave air rose after the warm season of 2014, almost doubling their concentration from around 2000 to about $4000 \mathrm{ppm}$. Using two specifically adapted types of air-water equilibrators, we were able to determine dissolved $\mathrm{CO}_{2}$ concentrations in drip water more easily and reliably than using the classical approach which depends on costly chemical analysis. We showed that drip water $\mathrm{CO}_{2}$ at the three monitored points is always greater than and not as homogenous as in cave air and can reach values as high as $11000 \mathrm{ppm}$. Our approach opens the way to cost effective logging of cave water $\mathrm{CO}_{2}$ that could be applied in speleothem science but also in show cave monitoring, where visitors are an important source of $\mathrm{CO}_{2}$. Moreover, these equilibrators could be used to sample any dissolved gas for concentration or stable isotopic measurements.

Studying monthly collected rain water samples at Drobeta and Isverna, we brought new isotope data from a region scarcely covered by the Global Network of Isotopes in
Precipitation (GNIP). The $\delta^{18} \mathrm{O}$ monthly values varied between $-15 \%$ in winter and $-4 \%$ in summer, while the 2015 weighted mean was $-9.36 \%$ at Isverna and $-8.31 \%$ at Drobeta. These values are comparable to weighted annual means for this region derived from GNIP data. The local meteoric water line is similar to the global one and deuterium excess values reach up to $16 \%$, much higher than those interpolated from GNIP. Modeling of back trajectories shows that most of the air masses that were present at our site during rainy days are of Atlantic origin, with reduced input from the Mediterranean. This suggests that the elevated deuterium excess values are mostly the result of Atlantic moisture being recycled over the European continent.

Drip water $\delta^{18} \mathrm{O}$ from Ascunsă Cave indicates the existence of a single, homogenous reservoir. Two enriched isotopic events in August and September 2014, as well as drip logging, indicate that water transfer time at Ascunsă Cave is on the order of days, via fracture flow.

Farmed calcite stable isotope analysis showed that the POM 2 site is not visibly affected by kinetic fractionation (as compared to the nearby POM X), making the stalagmite that formed here a good candidate for regional paleoenvironmental reconstruction.

Data availability. The Supplement related to this article contains the data used to plot Figs. 4 to 15 and 17 to 20 .

\section{The Supplement related to this article is available online at https://doi.org/10.5194/hess-21-5357-2017- supplement.}

Author contributions. VD designed the study, VD, SB, I, LT, and MV performed fieldwork, VD and SB designed the water-gas equilibrators, DB, VD, FLF, IM, VN and AP performed isotopic analysis, CM and AT performed chemical analysis, VD and LT modeled back trajectories of air masses, and IO performed statistical analysis. VD prepared the manuscript with contributions from all co-authors.

Competing interests. The authors declare that they have no conflict of interest.

Acknowledgements. This study was financially supported by the following grants: IFA-CEA C4-08 (FREem, Co-PIs Silviu Constantin and Dominique Blamart), 17 SEE (CAVEMONITOR, PI Silviu Constantin), PCE-2016-0197 (CARPATHEMS, PI Silviu Constantin), PN-II-RU-TE-2011-3-0235 (PI Aurel Perşoiu), PNII-RU-TE-2014-4-1993 (PI Aurel Perşoiu), 790/2014 (Co-PIs Aurel Perşoiu and Dominique Genty) and 18 SEE (PI Cățălin-Constantin Roibu). The authors gratefully acknowledge the NOAA Air Resources Laboratory (ARL) for the provision of the HYSPLIT transport and dispersion model used in 
this publication. We would like to thank two anonymous reviewers for their helpful comments, as well as Christine Stumpp for her valuable editorial work. We would also like to thank all our friends and colleagues who helped us during the last 4 years of fieldwork and especially to Emilian Isverceanu and his family for their continuous support.

Edited by: Christine Stumpp

Reviewed by: two anonymous referees

\section{References}

Aemisegger, F., Pfahl, S., Sodemann, H., Lehner, I., Seneviratne, S. I., and Wernli, H.: Deuterium excess as a proxy for continental moisture recycling and plant transpiration, Atmos. Chem. Phys., 14, 4029-4054, https://doi.org/10.5194/acp-144029-2014, 2014.

Apostol, L.: The Mediterranean cyclones-the role in ensuring water resources and their potential of climatic risk, in the east of Romania, Present environment and sustainable development, 2, 143-163, 2008

Atkinson, T. C.: Carbon dioxide in the atmosphere of the unsaturated zone: An important control of groundwater hardness in limestones, J. Hydrol., 35, 111-123, https://doi.org/10.1016/0022-1694(77)90080-4, 1977.

Baldini, J. U. L., McDermott, F., and Fairchild, I. J.: Spatial variability in cave drip water hydrochemistry: Implications for stalagmite paleoclimate records, Chem. Geol., 235, 390-404, https://doi.org/10.1016/j.chemgeo.2006.08.005, 2006.

Baltă, D. and Geicu, A.: Factorii dinamici ai atmosferei, in: Clima Romaniei, edited by: Sandu, I., Pescaru, V. I., Poiană, I., Geicu, A., Cândea, I., and Ţâştea, D., Editura Academiei Romane, Bucharest, 38-56, 2008.

Banner, J. L., Guilfoyle, A., James, E. W., Stern, L. A., and Musgrove, M.: Seasonal variations in modern speleothem calcite growth in Central Texas, USA, J. Sediment. Res., 77, 615-622, https://doi.org/10.2110/jsr.2007.065, 2007.

Bar-Matthews, M., Ayalon, A., Matthews, A., Sass, E., and Halicz, L.: Carbon and oxygen isotope study of the active watercarbonate system in a karstic Mediterranean cave, Geochim. Cosmochim. Ac., 60, 337-347, 1996.

Benavente, J., Vadillo, I., Carrasco, F., Soler, A., Liñán, C., and Moral, F.: Air Carbon Dioxide Contents in the Vadose Zone of a Mediterranean Karst, Vadose Zone J., 9, 126-136, https://doi.org/10.2136/vzj2009.0027, 2010.

Bojar, A.-V., Halas, S., Bojar, H.-P., and Chmiel, S.: Stable isotope hydrology of precipitation and groundwater of a region with high continentality, South Carpathians, Romania, Carpath. J. Earth Env., 12, 513-524, 2017.

Bojariu, R. and Paliu, D. M.: North Atlantic Oscillation Projection on Romanian Climate Fluctuations in the Cold Season, in: Detecting and Modelling Regional Climate Change, edited by: Brunet India, M. and Bonillo, D. L., Springer, Berlin Heidelberg, 345-356, 2001.

Breecker, D. O., Payne, A. E., Quade, J., Banner, J. L., Ball, C. E., Meyer, K. W., and Cowan, B. D.: The sources and sinks of $\mathrm{CO}_{2}$ in caves under mixed woodland and grass- land vegetation, Geochim. Cosmochim. Ac., 96, 230-246, https://doi.org/10.1016/j.gca.2012.08.023, 2012.

Broecker, W. S. and Takahashi, T.: Calcium carbonate precipitation on the Bahama Banks, J. Geophys. Res., 71, 1575-1602, https://doi.org/10.1029/JZ071i006p01575, 1966.

Brook, G. A., Folkoff, M. E., and Box, E. O.: A world model of soil carbon dioxide, Earth Surf. Proc. Land., 8, 79-88, https://doi.org/10.1002/esp.3290080108, 1983.

Brunt, D.: The adiabatic lapse-rate for dry and saturated air, Q. J. Roy. Meteor. Soc., 59, 351-360, https://doi.org/10.1002/qj.49705925204, 1933.

Chamberlain, C. P. and Poage, M. A.: Reconstructing the paleotopography of mountain belts from the isotopic composition of authigenic minerals, Geology, 28, 115-118, https://doi.org/10.1130/00917613(2000)28<115:rtpomb>2.0.co;2, 2000.

Craig, H.: Isotopic Variations in Meteoric Waters, Science, 133, 1702-1703, https://doi.org/10.1126/science.133.3465.1702, 1961.

Cruz, F. W., Burns, S. J., Karmann, I., Sharp, W. D., and Vuille, M.: Reconstruction of regional atmospheric circulation features during the late Pleistocene in subtropical Brazil from oxygen isotope composition of speleothems, Earth Planet. Sc. Lett., 248, 495-507, https://doi.org/10.1016/j.eps1.2006.06.019, 2006.

Dansgaard, W.: Stable isotopes in precipitation, Tellus, 16, 436468, https://doi.org/10.1111/j.2153-3490.1964.tb00181.x, 1964.

Delattre, H., Vallet-Coulomb, C., and Sonzogni, C.: Deuterium excess in the atmospheric water vapour of a Mediterranean coastal wetland: regional vs. local signatures, Atmos. Chem. Phys., 15, 10167-10181, https://doi.org/10.5194/acp-15-101672015, 2015.

D’Hulst, D.: STOCHASTOS Version 3.0 - Variables Regionalisees, Approche Statistique, CNRS, Laboratoire Souterrain Moulis, Saint Girons, 1994.

Dragotă, C., and Baciu, M.: Cantitţăile medii lunare şi anuale de precipitaţii, edited by: Sandu, I., Pescaru, V. I., and Poiană, I., Clima României, 245-264, 2008 (in Romanian).

Drăguşin, V., Staubwasser, M., Hoffmann, D. L., Érsek, V., Onac, B. P., and Vereş, D.: Constraining Holocene hydrological changes in the Carpathian-Balkan region using speleothem $\delta 180$ and pollen-based temperature reconstructions, Clim. Past, 10, 13631380, https://doi.org/10.5194/cp-10-1363-2014, 2014.

Draxler, R. R.: HYSPLIT4 user's guide, NOAA Tech. Memo. ERL ARL-230, NOAA Air Resources Laboratory, Silver Spring, MD, 1999.

Draxler, R. R. and Hess, G. D.: Description of the HYSPLIT_4 modeling system, NOAA Tech. Memo. ERL ARL-224, NOAA Air Resources Laboratory, Silver Spring, MD, 1997.

Draxler, R. R. and Hess, G. D.: An overview of the HYSPLIT_4 modeling system of trajectories, dispersion, and deposition, Aust. Meteorol. Mag., 47, 295-308, 1998.

Dreybrodt, W.: Evolution of the isotopic composition of carbon and oxygen in a calcite precipitating $\mathrm{H}_{2} \mathrm{O}-\mathrm{CO}_{2}-\mathrm{CaCO}_{3}$ solution and the related isotopic composition of calcite in stalagmites, Geochim. Cosmochim. Ac., 72, 4712-4724, https://doi.org/10.1016/j.gca.2008.07.022, 2008.

Dreybrodt, W. and Scholz, D.: Climatic dependence of stable carbon and oxygen isotope signals recorded in speleothems: From 
soil water to speleothem calcite, Geochim. Cosmochim. Ac., 75, 734-752, https://doi.org/10.1016/j.gca.2010.11.002, 2011.

Duan, W., Ruan, J., Luo, W., Li, T., Tian, L., Zeng, G., Zhang, D., Bai, Y., Li, J., Tao, T., Zhang, P., Baker, A., and Tan, M.: The transfer of seasonal isotopic variability between precipitation and drip water at eight caves in the monsoon regions of China, Geochim. Cosmochim. Ac., 183, 250-266, https://doi.org/10.1016/j.gca.2016.03.037, 2016.

Dumitru, O. A., Forray, F. L., Fornós, J. J., Ersek, V., and Onac, B. P.: Water isotopic variability in Mallorca: a path to understanding past changes in hydroclimate, Hydrol. Process., 31, 104-116, https://doi.org/10.1002/hyp.10978, 2017.

EPA: U Method 6020B. Inductively Coupled Plasma - Mass Spectrometry, Revision 2, 2014.

Faimon, J., Ličbinská, M., Zajíček, P., and Sracek, O.: Partial pressures of $\mathrm{CO}_{2}$ in epikarstic zone deduced from hydrogeochemistry of permanent drips, the Moravian karst, Czech Republic, Acta Carsologica, 41, 47-57, 2014.

Fairchild, I. J. and Baker, A.: Speleothem Science: From Process to Past Environments, Wiley-Blackwell, Chichester, 416 pp., 2012.

Fairchild, I. J., Smith, C. L., Baker, A., Fuller, L., Spötl, C., Mattey, D., and McDermott, F.: Modification and preservation of environmental signals in speleothems, Earth-Sci. Rev., 75, 105-153, 2006.

Feng, W., Casteel, R., C., Banner, J. L., and Heinze-Fry, A.: Oxygen isotope variations in rainfall, drip-water and speleothem calcite from a well-ventilated cave in Texas, USA: Assessing a new speleothem temperature proxy, Geochim. Cosmochim. Ac., 127, 233-250, https://doi.org/10.1016/j.gca.2013.11.039, 2014.

Ford, D. and Williams, P. D.: Karst hydrogeology and geomorphology, John Wiley \& Sons, 2013.

Gat, J. R.: Oxygen and hydrogen isotopes in the hydrologic cycle, Annu. Rev. Earth Planet. Sci., 24, 225-262, https://doi.org/10.1146/annurev.earth.24.1.225, 1996.

Gat, J. and Carmi, I.: Evolution of the isotopic composition of atmospheric waters in the Mediterranean Sea area, J. Geophys. Res., 75, 3039-3048, 1970.

Gat, J. R. and Carmi, I.: Effect of climate changes on the precipitation patterns and isotopic composition of water in a climate transition zone: Case of the Eastern Mediterranean Sea, Influence of Climatic Change on the Hydrological Regime and Water Resources, 513-523, 1987.

Gat, J. R., Klein, B., Kushnir, Y., Roether, W., Wernli, H., Yam, R., and Shemesh, A.: Isotope composition of air moisture over the Mediterranean Sea: an index of the air-sea interaction pattern, Tellus B, 55, 953-9-65, https://doi.org/10.1034/j.16000889.2003.00081.x, 2003.

Genty, D., Labuhn, I., Hoffmann, G., Danis, P. A., Mestre, O., Bourges, F., Wainer, K., Massault, M., Van Exter, S., Régnier, E., Orengo, Ph., Falourd, S., and Minster, B.: Rainfall and cave water isotopic relationships in two SouthFrance sites, Geochim. Cosmochim. Ac., 131, 323-343, https://doi.org/10.1016/j.gca.2014.01.043, 2014.

Hendy, C. H.: The isotopic geochemistry of speleothems-I. The calculation of the effects of different modes of formation on the isotopic composition of speleothems and their applicability as palaeoclimatic indicators, Geochim. Cosmochim. Ac., 35, 801824, https://doi.org/10.1016/0016-7037(71)90127-X, 1971.
Hu, C., Henderson, G. M., Huang, J., Chen, Z., and Johnson, K. R.: Report of a three-year monitoring programme at Heshang Cave, Central China, Int. J. Speleol., 37, 143-151, https://doi.org/10.5038/1827-806X.37.3.1, 2008.

IAEA/WMO: Global Network of Isotopes in Precipitation, The GNIP Database, available at: http://www.iaea.org/water, 2016.

Jex, C. N., Mariethoz, G., Baker, A., Graham P., Andersen, M. S., Acworth, I., Edwards, N., and Azcurra, C.: Spatially dense drip hydrological monitoring and infiltration behaviour at the Wellington Caves, South East Australia, Int. J. Speleol., 41, 283296, https://doi.org/10.5038/1827-806X.41.2.14, 2012.

Kim, S.-T. and O'Neil, J. R.: Equilibrium and nonequilibrium oxygen isotope effects in synthetic carbonates, Geochim. Cosmochim. Ac., 61, 3461-3475, https://doi.org/10.1016/S00167037(97)00169-5, 1997.

Klein Tank, A. M. G., Wijngaard, J. B., Können, G. P., Böhm, R., Demarée, G., Gocheva, A., Mileta, M., Pashiardis, S., Hejkrlik, L., Kern-Hansen, C., Heino, R., Bessemoulin, P., MüllerWestermeier, G., Tzanakou, M., Szalai, S., Pálsdóttir, T., Fitzgerald, D., Rubin, S., Capaldo, M., Maugeri, M., Leitass, A., Bukantis, A., Aberfeld, R., van Engelen, A. F. V., Forland, E., Mietus, M., Coelho, F., Mares, C., Razuvaev, V., Nieplova, E., Cegnar, T., Antonio López, J., Dahlström, B., Moberg, A., Kirchhofer, W., Ceylan, A., Pachaliuk, O., Alexander, L. V., and Petrovic, P.: Daily dataset of 20th-century surface air temperature and precipitation series for the European Climate Assessment, International J. Climatol., 22, 1441-1453, https://doi.org/10.1002/joc.773, 2002.

Lachniet, M. S.: Climatic and environmental controls on speleothem oxygen-isotope values, Quaternary Sci. Rev., 28, 412-432, https://doi.org/10.1016/j.quascirev.2008.10.021, 2009.

Lloyd, J. and Taylor, J. A.: On the Temperature Dependence of Soil Respiration, Funct. Ecol., 8, 315-323, https://doi.org/10.2307/2389824, 1994.

Mangin, A.: Pour une meilleure connaissance des systèmes hydrologiques à partir des analyses corrélatoire et spectrale, J. Hydrol., 67, 25-43, https://doi.org/10.1016/0022-1694(84)90230-0, 1984.

Mangin, A.: Karst hydrogeology, in: Groundwater Ecology, edited by: Stanford, J. A., Gilbert, J., and Danielopol, D. L., Academic Press, New York, 43-67, 1994.

Markowska, M., Baker, A., Andersen, M. S., Jex, C. N., Cuthbert, M. O., Rau, G. C., Graham, P. W., Rutlidge, H., Mariethoz, G., Marjo, C. E., Treble, P. C., and Edwards, N.: Semiarid zone caves: Evaporation and hydrological controls on $\delta 18 \mathrm{O}$ drip water composition and implications for speleothem paleoclimate reconstructions, Quaternary Sci. Rev., 131, 285-301, https://doi.org/10.1016/j.quascirev.2015.10.024, 2016.

Mattey, D., Lowry, D., Duffet, J., Fisher, R., Hodge, E., and Frisia, S.: A 53 year seasonally resolved oxygen and carbon isotope record from a modern Gibraltar speleothem: Reconstructed drip water and relationship to local precipitation, Earth Planet. Sc. Lett., 269, 80-95, https://doi.org/10.1016/j.epsl.2008.01.051, 2008.

Mattey, D. P., Fairchild, I. J., Atkinson, T. C., Latin, J.-P., Ainsworth, M., and Durell, R.: Seasonal microclimate control of calcite fabrics, stable isotopes and trace elements in modern speleothem from St Michaels Cave, Gibraltar, Geo- 
logical Society, London, Special Publications, 336, 323-344, https://doi.org/10.1144/SP336.17, 2010.

McDermott, F.: Palaeo-climate reconstruction from stable isotope variations in speleothems: a review, Quaternary Sci. Rev., 23, 901-918, https://doi.org/10.1016/j.quascirev.2003.06.021, 2004.

Meyer, K. W., Feng, W., Breecker, D. O., Banner, J. L., and Guilfoyle, A.: Interpretation of speleothem calcite $\delta 13 \mathrm{C}$ values: Evidence from monitoring soil $\mathrm{CO}_{2}$, drip water, and modern speleothem calcite in central Texas, Geochim. Cosmochim. Ac. 142, 281-298, https://doi.org/10.1016/j.gca.2014.07.027, 2014.

Noronha, A. L., Johnson, K. R., Southon, J. R., Hu, C., Ruan, J., and McCabe-Glynn, S.: Radiocarbon evidence for decomposition of aged organic matter in the vadose zone as the main source of speleothem carbon, Quaternary Sci. Rev., 127, 37-47, https://doi.org/10.1016/j.quascirev.2015.05.021, 2015.

Onac, B., P., Pace-Graczyk, K., and Atudirei, V.: Stable isotope study of precipitation and cave drip water in Florida (USA): implications for speleothem-based paleoclimate studies, Isotopes Environ. Health. Stud., 44, 149-161, https://doi.org/10.1080/10256010802066174, 2008.

Pfahl, S. and Sodemann, H.: What controls deuterium excess in global precipitation?, Clim. Past, 10, 771-781, https://doi.org/10.5194/cp-10-771-2014, 2014

Riechelmann, D. F. C., Schröder-Ritzrau, A., Scholz, D., Fohlmeister, J., Spötl, C., Richter, D. K., and Mangini, A.: Monitoring Bunker Cave (NW Germany): A prerequisite to interpret geochemical proxy data of speleothems from this site, J. Hydrol., 409, 682-695, https://doi.org/10.1016/j.jhydrol.2011.08.068, 2011

Riechelmann, D. F. C., Deininger, M., Scholz, D., Riechelmann, S., Schröder-Ritzrau, A., Spötl, C., Richter, D. K., Mangini, A., and Immenhauser, A.: Disequilibrium carbon and oxygen isotope fractionation in recent cave calcite: Comparison of cave precipitates and model data, Geochim. Cosmochim. Ac., 103, 232-244, https://doi.org/10.1016/j.gca.2012.11.002, 2013.

Sander, R.: Compilation of Henry's law constants (version 4.0) for water as solvent, Atmos. Chem. Phys., 15, 4399-4981, https://doi.org/10.5194/acp-15-4399-2015, 2015.

Smith, A. C., Wynn, P. M., Barker, P. A., Leng, M. J., Noble, S. R., and Stott, A.: Cave monitoring and the potential for palaeoclimate reconstruction from Cueva de Asiul, Cantabria (N. Spain), Int. J. Speleol., 45, 1-9, https://doi.org/10.5038/1827806X.45.1.1928, 2014.

Spötl, C., Fairchild, I. J., and Tooth, A. F.: Cave air control on dripwater geochemistry, Obir Caves (Austria): Implications for speleothem deposition in dynamically ventilated caves, Geochim. Cosmochim. Ac., 69, 2451-2468, 2005.
Stein, A. F., Draxler, R. R., Rolph, G. D., Stunder, B. J. B., Cohen, M. D., and Ngan, F.: NOAA's HYSPLIT atmospheric transport and dispersion modeling system, B. Am. Meteorol. Soc., 96, 2059-2077, doi10.1175/BAMS-D-14-00110.1, 2015.

Tooth, A. F. and Fairchild, I. J.: Soil and karst aquifer hydrological controls on the geochemical evolution of speleothem-forming drip waters, Crag Cave, southwest Ireland, J. Hydrol., 273, 5168, https://doi.org/10.1016/S0022-1694(02)00349-9, 2003.

Tremaine, D. M., Froelich, P. N., and Wang, Y.: Speleothem calcite farmed in situ: Modern calibration of $\delta 180$ and $\delta^{13} \mathrm{C}$ paleoclimate proxies in a continuously-monitored natural cave system, Geochim. Cosmochim. Ac., 75, 4929-4950, https://doi.org/10.1016/j.gca.2011.06.005, 2011.

U.S. Department of Commerce (DOC), National Oceanic and Atmospheric Administration (NOAA), National Weather Service (NWS), National Centers for Environmental Prediction (NCEP), and Environmental Modeling Center (EMC): Global Data Assimilation System (GDAS), Download source: ftp://arlftp. arlhq.noaa.gov/pub/archives/gdas0p5/ (last access: 24 November 2016), 2001

Van Rampelbergh, M., Verheyden, S., Allan, M., Quinif, Y., Keppens, E., and Claeys, P.: Monitoring of a fast-growing speleothem site from the Han-sur-Lesse cave, Belgium, indicates equilibrium deposition of the seasonal $\delta^{18} \mathrm{O}$ and $\delta^{13} \mathrm{C}$ signals in the calcite, Clim. Past, 10, 1871-1885, https://doi.org/10.5194/cp-10-18712014, 2014.

Verheyden, S., Genty, D., Deflandre, G., Quinif, Y., and Keppens, E.: Monitoring climatological, hydrological and geochemical parameters in the Père Noël cave (Belgium): implication for the interpretation of speleothem isotopic and geochemical time-series, Int. J. Speleol., 37, 221-234, https://doi.org/10.5038/1827806X.37.3.6, 2008.

White, W.: Geomorphology and Hydrology of Karst Terrains, Oxford University Press, New York, 1988.

White, W. B.: Karst hydrology: recent developments and open questions, Eng. Geol., 65, 85-105, https://doi.org/10.1016/S00137952(01)00116-8, 2002.

Wigley, T. M. L. and Brown, M. C.: The physics of caves, in: The Science of Speleology, edited by: Ford, T. D. and Cullingford C. H. D., Academy Press, London, 330-358, 1976. 